\title{
1,3-Diketone Calix[4]arene Derivatives-A New Type of Versatile Ligands for Metal Complexes and Nanoparticles
}

\author{
Sergey N. Podyachev *, Rustem R. Zairov and Asiya R. Mustafina
}

Citation: Podyachev, S.N.; Zairov, R.R.; Mustafina, A.R. 1,3-Diketone Calix[4]arene Derivatives-A New Type of Versatile Ligands for Metal Complexes and Nanoparticles. Molecules 2021, 26, 1214. https:// doi.org/10.3390/molecules26051214

Academic Editors: Vladislav Tomisic and Josip Pozar

Received: 1 February 2021

Accepted: 19 February 2021

Published: 24 February 2021

Publisher's Note: MDPI stays neutral with regard to jurisdictional claims in published maps and institutional affiliations.

Copyright: (c) 2021 by the authors. Licensee MDPI, Basel, Switzerland. This article is an open access article distributed under the terms and conditions of the Creative Commons Attribution (CC BY) license (https:/ / creativecommons.org/licenses/by/ $4.0 /)$.
Arbuzov Institute of Organic and Physical Chemistry, FRC Kazan Scientific Center of RAS, 8 Arbuzov str., Kazan 420088, Russia; rustem02@yandex.ru (R.R.Z.); asiyamust@mail.ru (A.R.M.)

* Correspondence: spodyachev@gmail.com; Tel.: +7-843-273-45-73; Fax: +7-843-273-18-72
Keywords: calixarenes; 1,3-diketone; macrocycles; ligands; lanthanides; complexation; supramolecular chemistry; luminescence; nanoparticle

\section{Introduction}

Calix[n]arene chemistry had been a top of current interest from late 1980 to early 2000 [1-6], although up to now calix[n]arene backbones are still relevant as building blocks of different functional materials [7-11]. Calix[4]arenes, thiacalix[4]arenes and calix[4]resorcinarenes are the most widely applied scaffolds among other calix[n]arenes for embedding of different groups [12-15]. The stability of a cone-conformation, in turn, opens new opportunities for the preorganization of functional groups, which is of great advantage in developing of ligands and extractants [16-18]. The 1,3-diketone derivatives have been well-documented as both promising precursors in organic synthesis $[19,20]$ and as promising compounds in drug design [21,22], although the greatest attention has been focused on their complex ability [23]. The latter is greatly affected by the structure of 1,3-diketones, since their complexation with metal ions results from the alkaline-driven diketone-to-diketonate transformation undergoing through the keto-enol equilibrium shift.

The complex ability of the 1,3-diketone-based ligands can be controlled by their structural diversifications based on both variation of the substituents and joining several 1,3-diketone moieties in one molecule leading to the so-called poly-diketones [24,25]. The latter have been documented as promising building blocks in development of the MOFbased structures [26,27].

Among other metal complexes, lanthanide 1,3-diketone derivatives have attracted the greatest interest due to the documented impact of the 1,3-diketonate ligands on sensitizing of lanthanide-centered luminescence through a ligand-to-metal energy transfer [23,28-30]. The aforesaid capacity prompts great diversity of 1,3-diketone derivatives as the ligands for lanthanide ions. The lanthanide complexes with 1,3-diketonates provide good basis for developing of sensors [31]. The sensing ability of lanthanide complexes with 1,3-diketonates 
has recently been exemplified by sensitivity of lanthanide-centered luminescence to temperature and $\mathrm{pH}$ changes, sensing of antibiotics, pressure-induced phase transition [32-41].

(1) Thus, the present review is focused on synthetic and structural aspects of calix[4]arene, thiacalix[4]arene and calix[4]resorcinarenes as scaffolds for embedding of 1,3-diketone moieties.

(2) The structural features of the cyclophanic 1,3-diketones will be correlated with their ability to complex lanthanide ions and to feed lanthanide-centered excited states through the ligand-to-metal energy transfer.

(3) The different modes of conversion of lanthanide 1,3-diketonate complexes from molecular to water-dispersible nanoparticulate forms will be also discussed herein as a prerequisite for their applicability for bio-sensing and bio-imaging. The structureproperty relationships of the complexes in nanoparticulate forms will be correlated with their sensing and imaging functions.

\section{Synthesis of the 1,3-Diketone Calix[4]arene Derivatives}

Synthesis of the calix[4]arenes functionalized by 1,3-diketone groups was first reported by Shinkai group (1994) [42]. The addition of potassium tert-butoxide and KI to the dichloromethylated calix[4] arene $\mathbf{1}$ and acetylacetone (HAA) in tert-butanol solution (Scheme 1) resulted in the isolation of calix[4]arene 2 in a good yield (74\%). Unfortunately, neither synthetic protocol nor spectral characteristics of the bis-1,3-diketone 2 were reported in the article apart from the scheme of the synthesis.
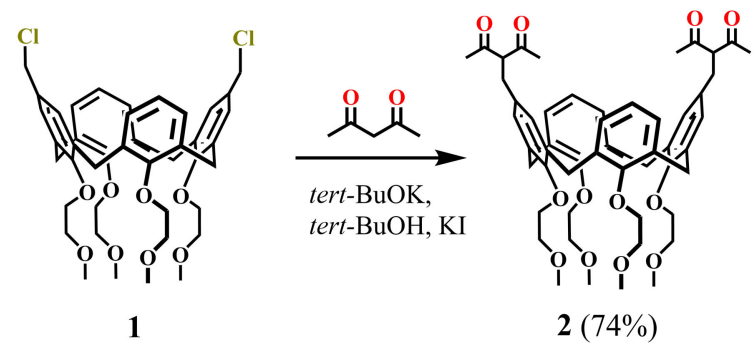

Scheme 1. Preparation of bis-1,3-diketone calix[4]arene 2.

The synthetic strategy for the embedding of one 1,3-diketone group onto the upper or lower rims of calix[4]arenes was developed by Senthilvelan et al. (2006) a decade later [43] (Scheme 2). To obtain these compounds, the isoxazoline derivatives 3a-d or $\mathbf{6 a - c}$ were heated in acetonitrile in the presence of catalyst $\mathrm{Mo}(\mathrm{CO})_{6}$ and few drops of water, which was resulted in the ring opening and formation of 1,3-diketone derivatives $4 \mathbf{a}-\mathbf{d}$ and $7 \mathbf{a}-\mathbf{c}$. The authors noted that along with the formation of the target products $4 \mathbf{a}-\mathbf{c}$, the disproportionation of the initial isoxazoline derivatives also took place with a formation of a noticeable amount (15-32\%) of unsubstituted calix[4]arene 5. The yield of the target products $4 \mathbf{a}-\mathbf{c}$ and $\mathbf{7 a - c}$ was only $30-55 \%$. In the case of the compound $4 \mathbf{d}$ bearing an amide group at the lower rim, the disproportionation did not occur, and the yield of the product reached $75 \%$. The formation of the desired 1,3-diketones was not observed even under the use of the $\mathrm{H}_{2} / \mathrm{Pd}-\mathrm{C}$ system to open the isoxazole ring.

This method, according to the authors opinion, is rather effective and convenient for the preparation of the calix[4]arenes bearing 1,3-diketone fragments both at the lower and upper rims of the macrocycle. However, it is worth noting a relatively low yield of the reaction, strong requirements for the choice of the catalyst, a rather effortful synthesis of the starting isoxazoline derivatives and a possibility of disproportionation of the starting reagents during the reaction as the factors complicating the usage of this approach for the synthesis of calix[4]arene 1,3-diketones. 

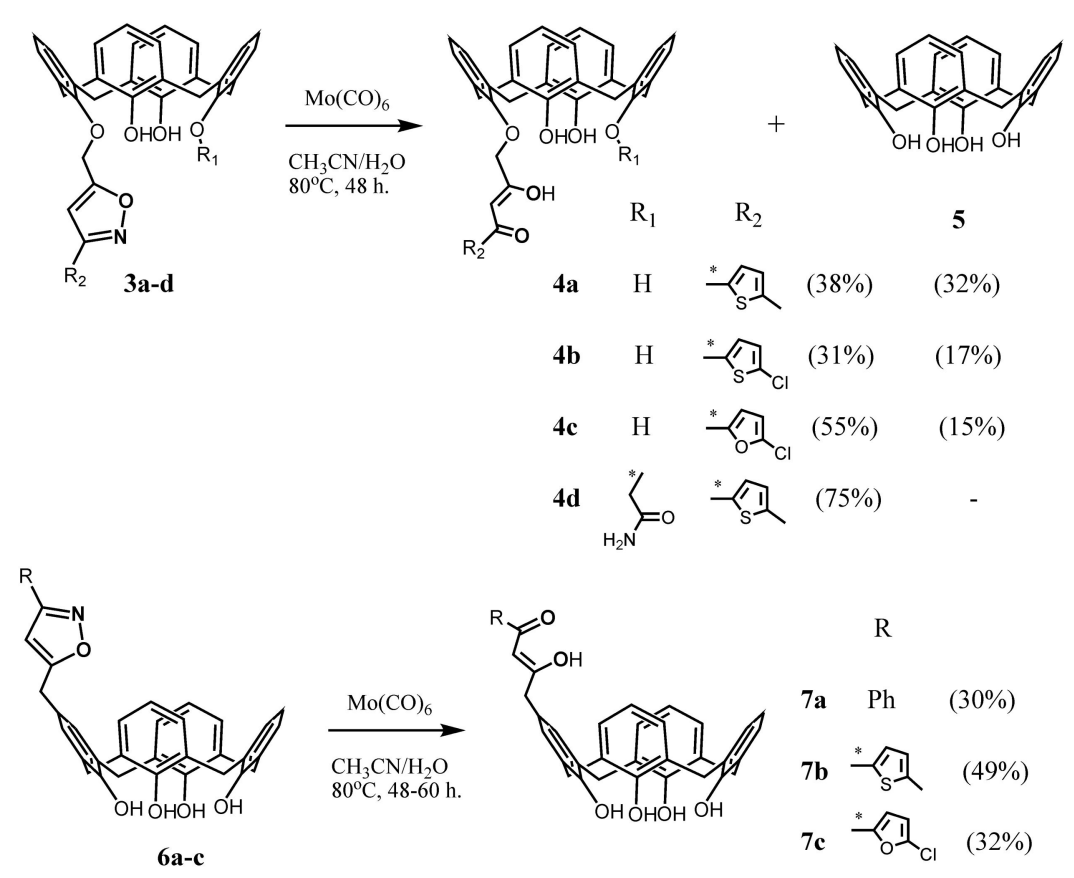

Scheme 2. Preparation of mono-1,3-diketone derivatives of calix[4]arene $4 \mathbf{a}-\mathbf{d}$ and $\mathbf{7 a}-\mathbf{c}$.

Biali et al. were the first who functionalized the calix[4]arene (2011) [44], calix[5]arene (2009) [45], calix[6]arene (2008) [46] and calix[8]arene (2011) [47] by 1,3-diketone fragments at the bridging carbon atoms of the macrocycles (Schemes 3 and 4). At the first stage, one of two bridging hydrogen atoms in the starting methoxy-substituted calix[n]arenes $\mathbf{8 a}, \mathbf{b}$ was replaced by a bromine or chlorine atom. Thus, the bromination of calix[5]arene 8a and calix[6]arene $\mathbf{8 b}$ was carried out by the reflux them in $\mathrm{CCl}_{4}$ with a slight excess of N-bromosuccinimide and light irradiation (Scheme 3) $[45,46]$.

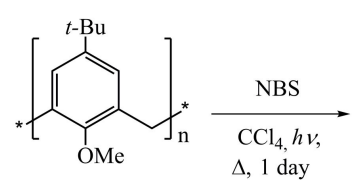

$\mathbf{8 a} \mathrm{n}=5$

$\mathbf{8 b} \mathrm{n}=6$

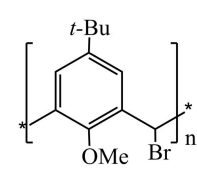

9a $\mathrm{n}=5(71 \%)$ $9 \mathrm{~b} \mathrm{n}=6(54 \%)$

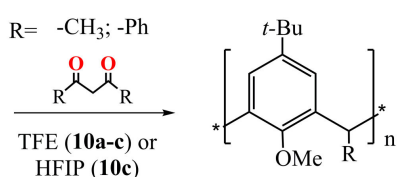

10a $\mathrm{n}=5 \quad \mathrm{R}=\mathrm{CH}(\mathrm{COMe})_{2} \quad(23 \%)$

$10 \mathrm{~b} n=5 \quad \mathrm{R}=\mathrm{CH}(\mathrm{COPh})_{2} \quad(10 \%)$

$10 \mathrm{c} n=6 \quad \mathrm{R}=\mathrm{CH}(\mathrm{COMe})_{2} \quad$ (TFE: $51 \%$; HFIP: $\left.62 \%\right)$

Scheme 3. Preparation of penta-1,3-diketone derivatives of calix[5]arene $\mathbf{1 0 a}, \mathbf{b}$ and hexa-1,3-diketone calix[6]arene 10c.<smiles>COc1c(C)cc(Br)cc1C(Cl)(Cl)c1cc(Br)cc(CC(C)(C)C)c1OC</smiles>

11

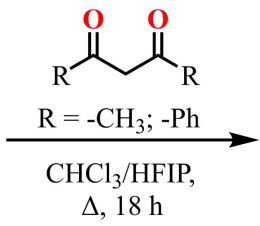

$\Delta, 18 \mathrm{~h}$<smiles>[R]C(CC)c1cc(Br)cc(CC)c1OC</smiles>

12a $\mathrm{R}=\mathrm{CH}(\mathrm{COMe})_{2}(29 \%)$

12b $\mathrm{R}=\mathrm{CH}(\mathrm{COPh})_{2} \quad(41 \%)$

Scheme 4. Preparation of mono-1,3-diketone derivatives of calix[8]arene 12a,b.

The reflux of the pentabromocalix[5]arene derivative 9a with HAA or dibenzoylmethane (HDBM) in the ionizing solvent 2,2,2-trifluoroethanol (TFE) under addition of several drops of $\mathrm{HBr}$ led to the formation of penta-1,3-diketone calix[5]arenes 10a and 10b (Scheme 3). Similarly, the interaction of $\mathbf{9 b}$ with HAA gave the hexa-substituted 
calix[6]arene 10c. The yield of the target product appeared to increase significantly with an increase of the size of the macrocycle (from $23 \%$ for calix [5]arene 10a to $51 \%$ for calix[6]arene 10c). The replacement of the TFE solvent with 1,1,1,3,3,3-hexafluoroisopropanol (HFIP) in the synthesis of compound 10c also increased the yield of the reaction up to $62 \%$. The authors supposed that the reaction proceeds in accordance with $S_{N} 1$ mechanism through the replacing of the halogen with a central carbon atom of the 1,3-diketone group. The structure of compound 10c is characterized by the cis- (equatorial) arrangement of all 1,3-diketone fragments. The ${ }^{1} \mathrm{H}$ NMR spectra of this compound in $\mathrm{CDCl}_{3}$ and DMSO- $d_{6}$ solutions revealed no signals of the enol form.

Later, the calix[8]arene derivatives 12a, $\mathbf{b}$ with one 1,3-diketone group attached to the methylene bridge of the macrocycle were obtained (Scheme 4) by the reflux of monochlorosubstituted calix[8]arene $\mathbf{1 1}$ with HAA or HDBA in a mixture of chloroform and HFIP [47].

The group of Biali S.E. succeeded in the synthesis of bis-1,3-diketone calix[4]arene derivative 14 (Scheme 5) [44] which was obtained by the reflux of dibromo-substituted calix[4]arene 13 bearing two carbonyl groups at the lower bridge with an excess of HAA in trifluoroacetic acid. A mutual trans-orientation of the chelate substituents at the macrocyclic platform appeared to be a peculiarity of the compound 14. The absence of $\mathrm{OH}$ signals in ${ }^{1} \mathrm{H}$ NMR spectrum of this compound indicates that only the keto form for 1,3-diketone fragments is realized in the $\mathrm{CDCl}_{3}$ solution.

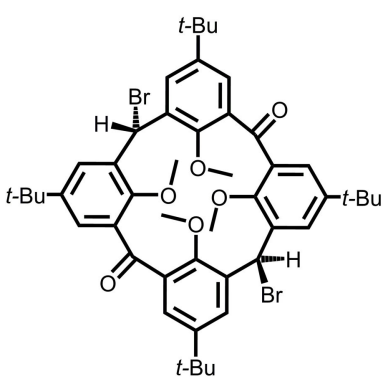

13

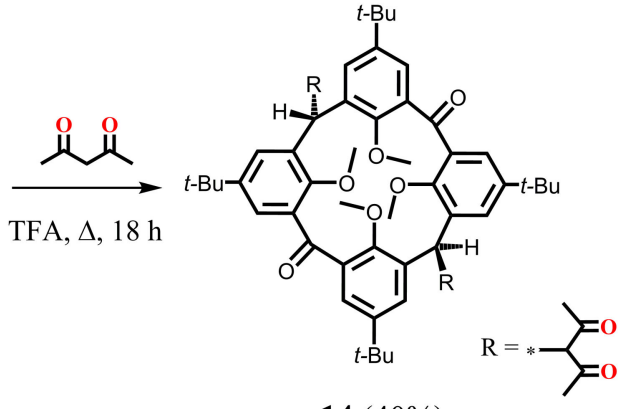

$14(40 \%)$

Scheme 5. Preparation of bis-1,3-diketone derivative of calix[4]arene 14.

Jiang et al. (2014) [48] presented the synthesis of two types of calix[4]arenes 16a,b bearing 1,3-diketone substituents at their upper rims and differentiating in the size of macrocyclic cavities (Scheme 6). For their preparation, 2,2,2-methoxy-4,5-dimethyl-1,3,2 $\lambda^{5}$ dioxaphosphole calix [4]arene derivatives $\mathbf{1 5 a}$ and $\mathbf{1 5 b}$ were refluxed in $\mathrm{MeOH}$ solution during $2 \mathrm{~h}$ giving the tetra-1,3-diketones $\mathbf{1 6 a}$ and $\mathbf{1 6 b}$ in $35 \%$ yield. The authors noted that the synthesis of $\mathbf{1 6 b}$ was accompanied by a mixture of mono-, di-, tri-, and tetra1,3-diketone calix[4]arene derivatives. Therefore, the target product was isolated using chromatography followed by recrystallization.

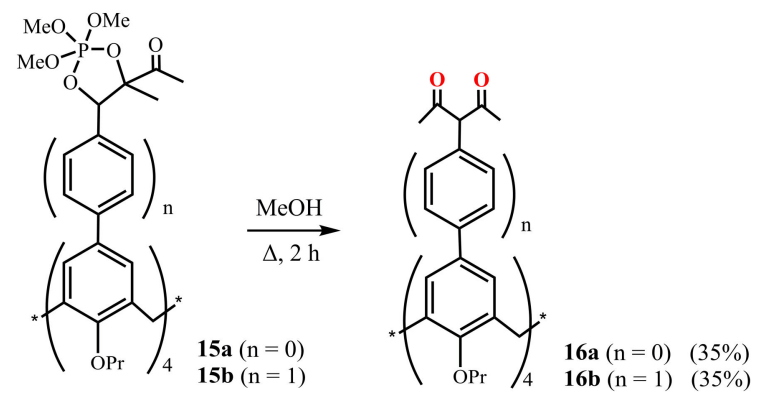

Scheme 6. Preparation of tetra-1,3-diketone derivatives of calix[4]arene 16a,b. 
Luo et al. (2014-2015) [49-51] reported the synthesis of bis-1,3-diketone calix[4]arene derivatives 18-21, where the chelate groups were located at the lower rim of the macrocycle (Scheme 7). For this purpose, the Claisen condensation was carried out between diester calix[4] arene derivatives $\mathbf{1 7} \mathbf{a}, \mathbf{1 7} \mathbf{b}$ and para-substituted acetophenones in the presence of 1.5 excess of $\mathrm{NaH}$ in THF. The isolated products were purified using chromatography column. The yield of bis-1,3-diketones 18a-e, 19a-e was $42-71 \%$, and in the case of their analogues $\mathbf{2 0 a}-\mathbf{d}$ and $\mathbf{2 1 a}-\mathbf{d}$ containing triazole fragments, it turned out to be noticeably lower-33-52\%. The resulting compounds have the cone isomeric form. The presence of $\mathrm{OH}$-proton signals in the ${ }^{1} \mathrm{H}$ NMR spectra of the synthesized bis-1,3-diketones 18-21 indicated a significant content of the enol form for these compounds. It should be noted that, unfortunately, our attempts to reproduce the synthesis of bis-1,3-diketone 18a were unsuccessful, and no target product was found in the reaction mixture.

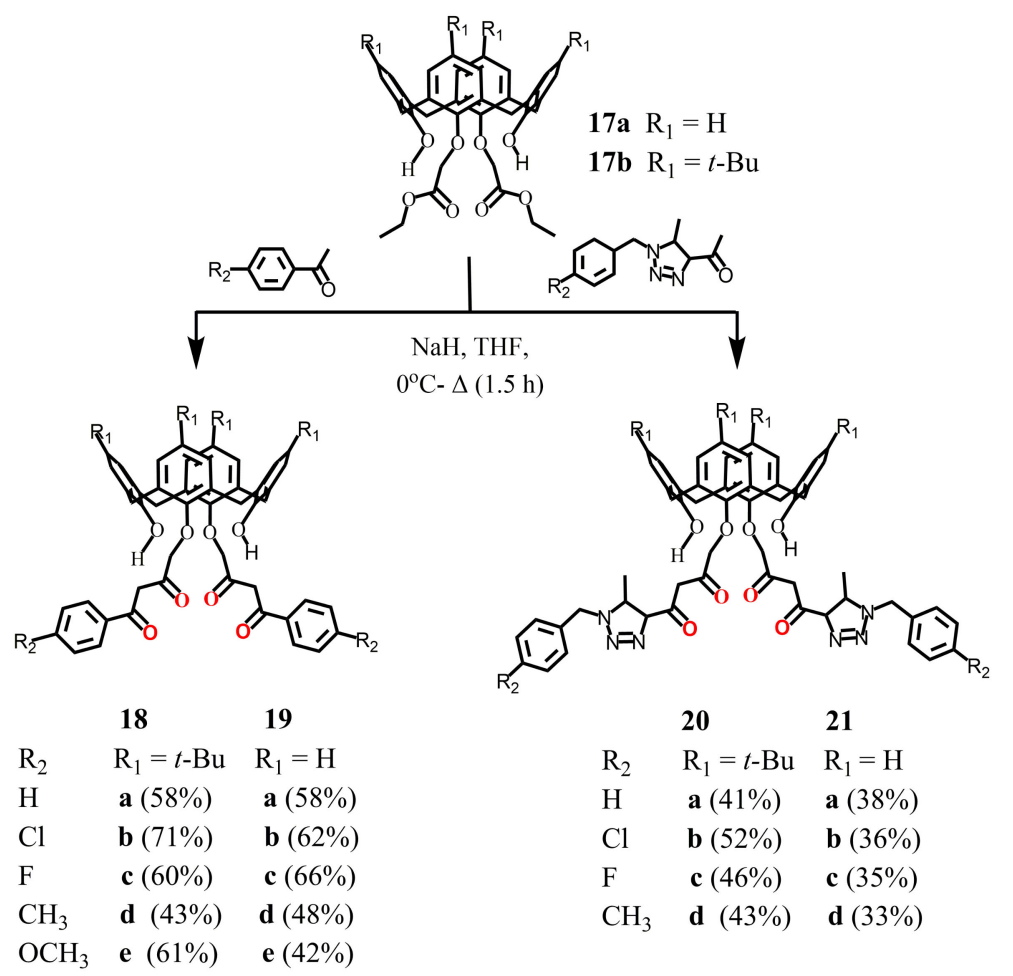

Scheme 7. Synthesis of bis-1,3-diketone derivatives of calix[4]arene 18-21.

The side processes accompanying synthesis of poly-1,3-diketones can lead to a significant decrease in the yield of target products in comparison with the mono-derivatives. Sometimes it makes the synthesis of poly-1,3-diketones completely impossible. Moreover, several reaction centers and high molecular weights of calix[4]arenes complicates the synthesis of poly-1,3-diketones. Thus, an introduction of the previously prepared 1,3-diketone blocks into the macrocycle backbone may be considered as a more successful strategy for the obtaining of diketo-derivatives of calix[4]arenes. We have successfully used this approach earlier for the synthesis of tris-1,3-diketones based on the mesitylene platform [52], and the Shinkai group first applied it for the synthesis of bis-1,3-diketone calix[4]arene 2 [42]. In particular, the embedding of two or four 1,3-diketone groups onto upper rims of calix[4]resorcinarene, calix[4]arene and thiacalix[4]arene backbones was fulfilled by the substitution reactions of the previously prepared sodium salts of 1,3-diketones with the halogenmethylated macrocycles.

Thus, the reflux of tetra-bromomethylated calix[4]resorcinarene cavitand 22 or tetrachloromethylated calix[4]arene $24 \mathbf{a}$ with an excess of sodium acetylacetonate (NaAA) in dioxane resulted in the tetra-1,3-diketones 26 [53] and 28a [54], respectively, in good yields 
(Scheme 8 ). However, in the case of calix[4]arene $\mathbf{2 4 \mathbf { b }}$ with long alkyl substituents, a generation of by-products due to the cleavage of diketone fragments was observed [55]. A lowering of the reaction temperature together with using of methyl isobutyl ketone (MIBK)dimethylformamide (DMF) mixture instead of dioxane and addition of $\mathrm{NaI}$ enabled to avoid the by-products formation and to get the pure product $\mathbf{2 8 b}$.

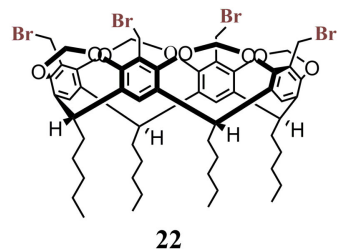

22

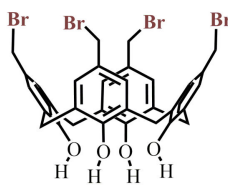

23

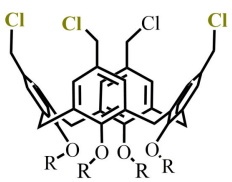

24a $\mathrm{R}=\mathrm{C}_{3} \mathrm{H}_{7}$ 24б $\mathrm{R}=\mathrm{C}_{9} \mathrm{H}_{19}$

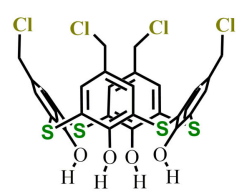

25
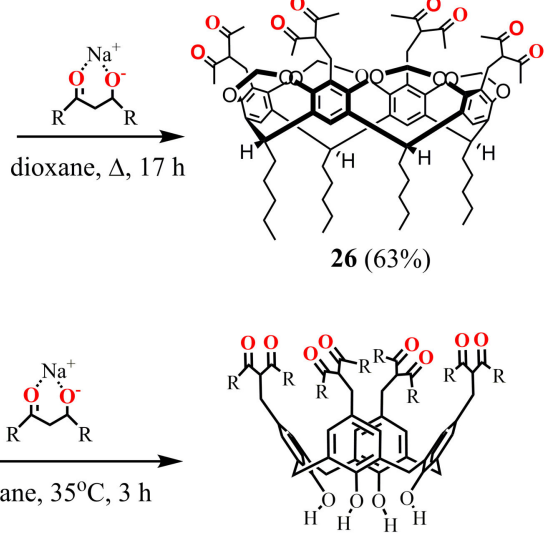

27a $\mathrm{R}=\mathrm{CH}_{3} \quad(65 \%)$

27б $\mathrm{R}=\mathrm{C}\left(\mathrm{CH}_{3}\right)_{3}(40 \%)$

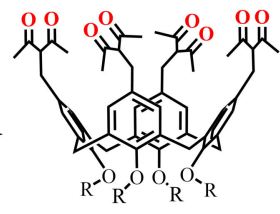

28a $\mathrm{R}=\mathrm{C}_{3} \mathrm{H}_{7}(77 \%)$

28б $\mathrm{R}=\mathrm{C}_{9} \mathrm{H}_{19}(62 \%)$

for 28a: dioxane, 1 day, $\Delta$

(2:1), NaI, 1 day, $60^{\circ} \mathrm{C}$
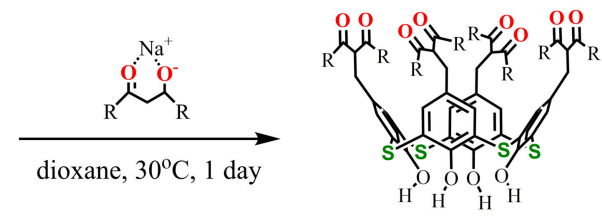

29a $\mathrm{R}=\mathrm{CH}_{3} \quad(60 \%)$ 29б $\mathrm{R}=\mathrm{C}\left(\mathrm{CH}_{3}\right)_{3}(43 \%)$

Scheme 8. Synthesis of tetra-1,3-diketone derivatives of calix[4]resorcinarene $\mathbf{2 6}$, calix[4]arene 27a,b, $\mathbf{2 8 a}, \mathbf{b}$ and thiacalix[4]arene $\mathbf{2 9 a}, \mathbf{b}$.

Halogenomethylated derivatives of calix[4]arenes with alkyl substituents at the lower rim usually possess lower reactivity in comparison with their counterparts unsubstituted at the lower rim. Thus, the nucleophilic substitution of calix[4]arene 23 with NaAA or a sodium salt of dipivaloylmethane $(\mathrm{NaDPM})$ proceeds even at room temperature and completes in a rather short time in contrast to the compound 24a [54]. The chloromethylated analogue of $\mathbf{2 3}$ is known to be a highly reactive compound, especially under basic conditions [56,57]. It easily loses $\mathrm{HCl}$ to give the corresponding $p$-quinone methide which undergoes further transformations. The intensive reddening of the reaction mixture observed in 10-15 min after adding NaAA to the calix[4]arene 23, is followed by the disappearance of color when the reaction is completed. These facts clearly indicate the formation of an intermediate quinone structure in the solution. The reaction with thiacalix[4]arene $\mathbf{2 5}$ proceeds in a similar way, giving the tetra-1,3-diketone derivatives $\mathbf{2 9 a}, \mathbf{b}$ [58] with the same yields as $\mathbf{2 7} \mathbf{a}, \mathbf{b}$. 
For the synthesis of bis-1,3-diketone calix[4]arene unsubstituted at the lower rim, the dibromomethylated derivative 31 was applied, being prepared at room temperature under interaction of calix[4]arene $\mathbf{3 0}$ with three equivalents of paraformaldehyde and $\mathrm{HBr}$ in glacial acetic acid solution in the presence of catalytic amount of $\mathrm{Zn}$ [55]. The addition of 1,3-diketone sodium salt to dibromomethylated calix[4]arene $\mathbf{3 1}$ was accompanied by the appearance of an intense pink-violet color caused apparently by the formation of $p$-quinone methide intermediates in the solution. At the end of reaction, the target bis-1,3-diketones 32a-c were isolated with $52-60 \%$ yields [55].

The approach represented by Scheme 9 cannot be applied for the synthesis of bis1,3-diketone calix[4]arene derivatives having substituents at the lower macrocyclic rim due to low reactivity of the substituted calix[4]arenes. However, the halogenmethylation of such calix[4]arenes can be performed by the addition of an excess of chloromethyl methyl ether and $\mathrm{SnCl}_{4}$. In the case of thiacalix[4]arene, this reaction proceeds only for the macrocycle unsubstituted at the lower rim. On the whole, the possible formation of both structural isomers and differently substituted by-products under the excess of the reagents complicates the controlled preparation of the distally substituted dichloromethylated derivatives. In this connection, a more general approach has been developed, based on the usage of dibromo-calix[4]arenes 33, 34 and 39a-d (Scheme 10).

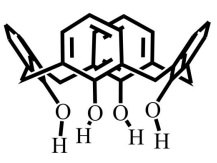

30

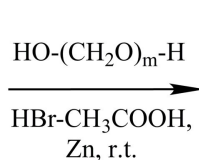

$\mathrm{Zn}$, r.t.

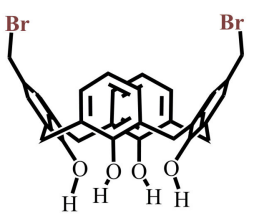

31

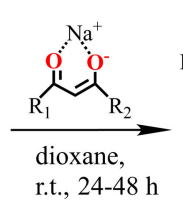

r.t., $24-48 \mathrm{~h}$

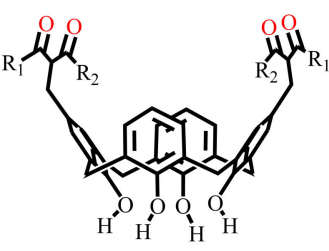

32a $\mathrm{R}_{1}=\mathrm{R}_{2}=\mathrm{CH}_{3} \quad(52 \%)$ 32b $\mathrm{R}_{1}=\mathrm{CH}_{3}, \mathrm{R}_{2}=\mathrm{Ph}(60 \%)$ 32c $\mathrm{R}_{1}=\mathrm{R}_{2}=\mathrm{Ph} \quad(55 \%)$

Scheme 9. Synthesis of bis-1,3-diketone derivatives of calix[4]arene 32a-c.

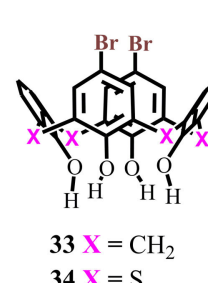

$34 \mathrm{X}=\mathrm{S}$

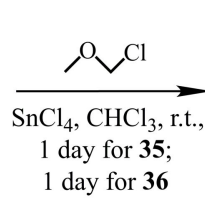

1 day for 36

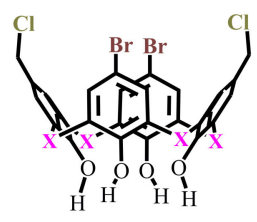

$35(83 \%)$ $36(86 \%)$

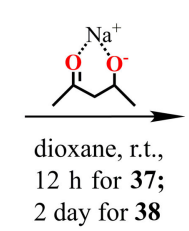

2 day for 38

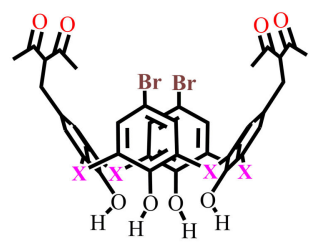

$37 \mathrm{X}=\mathrm{CH}_{2}(60 \%)$ $38 \mathrm{X}=\mathrm{S}(45 \%)$

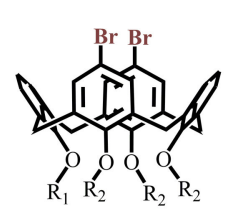

39a $\mathrm{R}_{1}=\mathrm{R}_{2}=\mathrm{C}_{3} \mathrm{H}_{7}$ 39b $\mathrm{R}_{1}=\mathrm{R}_{2}=\mathrm{C}_{9} \mathrm{H}_{19}$ 39c $\mathrm{R}_{1}=\mathrm{C}_{3} \mathrm{H}_{7}, \mathrm{R}_{2}=2-\mathrm{CH}_{2}-\mathrm{Py}$ 39d $\mathrm{R}_{1}=\mathrm{C}_{3} \mathrm{H}_{7}, \mathrm{R}_{2}=2-\mathrm{CH}_{2}$-Quin

$$
2-\mathrm{CH}_{2}-\mathrm{Py} \longrightarrow
$$
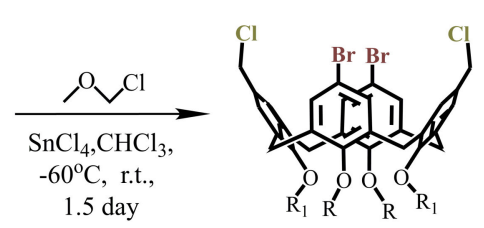

40a $\mathrm{R}_{1}=\mathrm{R}_{2}=\mathrm{C}_{3} \mathrm{H}_{7}(79 \%)$

40b $\mathrm{R}_{1}=\mathrm{R}_{2}=\mathrm{C}_{9} \mathrm{H}_{19}(70 \%)$

40c $\mathrm{R}_{1}=\mathrm{C}_{3} \mathrm{H}_{7}, \mathrm{R}_{2}=2-\mathrm{CH}_{2}-\mathrm{Py}(50 \%)$

40d $\mathrm{R}_{1}=\mathrm{C}_{3} \mathrm{H}_{7}, \mathrm{R}_{2}=2-\mathrm{CH}_{2}$-Quin (62\%)

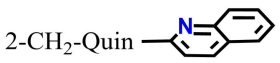

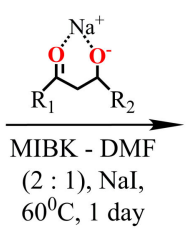

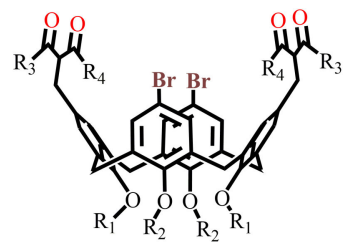

$\mathrm{R}_{1} \quad \mathrm{R}_{2}$

$\mathrm{R}_{3} \quad \mathrm{R}_{4}$

41a $\mathrm{C}_{3} \mathrm{H}_{7} \quad \mathrm{C}_{3} \mathrm{H}_{7} \quad \mathrm{CH}_{3} \quad \mathrm{CH}_{3}(51 \%)$

41b $\mathrm{C}_{3} \mathrm{H}_{7} \quad \mathrm{C}_{3} \mathrm{H}_{7} \quad \mathrm{CH}_{3} \mathrm{Ph} \quad(50 \%)$

41c $\mathrm{C}_{3} \mathrm{H}_{7} \quad \mathrm{C}_{3} \mathrm{H}_{7} \quad \mathrm{Ph} \quad \mathrm{Ph} \quad(68 \%)$

41d $\mathrm{C}_{9} \mathrm{H}_{19} \quad \mathrm{C}_{9} \mathrm{H}_{19} \quad \mathrm{CH}_{3} \mathrm{CH}_{3}(73 \%)$

41e $\mathrm{C}_{3} \mathrm{H}_{7} 2-\mathrm{CH}_{2}$-Py $\mathrm{CH}_{3} \mathrm{CH}_{3} \quad(55 \%)$

41f $\mathrm{C}_{3} \mathrm{H}_{7} 2-\mathrm{CH}_{2}$-Quin $\mathrm{CH}_{3} \mathrm{CH}_{3}(60 \%)$

Scheme 10. Synthesis of dibromo-bis-1,3-diketone derivatives of calix[4]arene 37,41 and thiacalix[4] arene 38 . 
The synthesis of compounds 33 [59] and 34 [60] was carried out by means of protection and deprotection procedures using a benzoyl group, as well as by introduction of bromine atoms at the upper rim of calix[4]arene applying $\mathrm{Br}_{2}$. Dibromo-calix[4]arenes $39 \mathbf{a}, \mathbf{b}$ with alkyl substituents were obtained by the procedures of dialkylation, bromination, and alkylation of the remaining hydroxyl groups. Calix[4]arenes $39 \mathrm{c}$, d with pyridine or quinoline fragments at the lower rim of the macrocycle [61] were synthesized in a similar way, where the pyridine or quinoline groups were introduced at the first stages of the synthesis. The reaction of these compounds with an excess of chloromethyl methyl ether and $\mathrm{SnCl}_{4}$ yielded dichloromethylated derivatives 35,36 and $40 \mathrm{a}-\mathrm{d}$ which, being reacted with sodium salts of 1,3-diketones, gave the target bis-1,3-diketones 37,38 and $\mathbf{4 1 a}-\mathbf{f}$ with good yields (Scheme 10).

Thus, all 1,3-diketone derivatives presented in the literature were obtained on the basis of "classical" calix[4]arenes functionalized at both upper and lower rims. There are also several examples of calix[4,5,6 and 8]arenes with chelating groups attached to the methylene bridges of these macrocycles. To obtain all these compounds, various synthetic methods were studied. Many of these methods, however, have a rather limited application and often are accompanied by a low yield. We have developed a more general and efficient approach to the preparation of poly-1,3-diketones, based on the reaction of nucleophilic addition of 1,3-diketones to the halogenmethyl derivatives of calix[4]arene. Applying this approach, we succeeded in obtaining of a wide range of bis- and tetra-1,3diketone derivatives of calix[4]arene, thiacalix[4]arene, and calix[4]resorcinarene, including bifunctional bis-1,3-diketone calix[4]arene derivatives.

\section{Keto-Enol Tautomeric Transformation of 1,3-Diketone calix[4]arene Derivative}

A keto-enol tautomeric transformation of 1,3-diketones represented in Scheme 11 is the most widely documented property of the 1,3-diketone derivatives [62-66]. The extent of enol form of 1,3-diketones in solutions tends to increase under dilution of the latter or under decreasing a solvent polarity $[23,62,67]$. Literature data reveal great impact of both $\alpha$ - and $\beta$-carbon substitution on the keto-enol transformation, because thermodynamic stabilization of the enolate form requires the charge delocalization, which is facilitated by the planar localization of both $\beta$-carbon substituents and keto-groups in the cis-localization (Scheme 11). Indeed, the bulky $\alpha$-carbon substituents destabilize the cis-enol form [68], while the greater bulkiness of $\beta$-carbon substituents exemplified by methyl, tert-butyl and phenyl moieties enhance the extent of the enolic form. The pronounced enhancement of this form for phenyl-substituted 1,3-diketone derives from facilitating the $\pi$-delocalization around the enol ring [62].<smiles>[R]C(=O)C([R])([R])C(=O)CC</smiles>

keto form<smiles></smiles>

enol form<smiles>[R]C(=O)C([R])C([R])O</smiles>

$\mathrm{R}^{2}$<smiles>[R]C1=C([R])C([R])O[Y10]O1</smiles>

Scheme 11. Keto-enol transformation of 1,3-diketones, 1,3-diketonates and their complexes with metal ions.

Literature data analysis reveals an impact of the embedding mode of 1,3-diketo-groups onto cyclophanic backbones on the keto-enol transformations. In particular, the lack of enolic form is observed when 1,3-diketo-groups are embedded via bridging methylenegroup (14 in Scheme 5), while the enolic form is predominant when 1,3-diketone moieties are embedded through the lower rim of calix[4]arene (18-21 in Scheme 7). In particular, 1,3-diketone 19e in crystalline state was revealed in enol form (Figure 1a) [49]. The contribution of enolic form is also high $(30-50 \%)$ under the upper-rim substitution of acetylacetone groups (27-29 in Table 1). The embedding of acetylacetone moieties onto 
calix[4]resorcinarene cavitand $\mathbf{2 6}$ (Figure $1 \mathrm{~b}$ ) via $\alpha$-carbon substituted methylene groups significantly restricts the keto-enol transformation which results in the predominance of the keto-form in crystalline state of $\mathbf{2 6}$ and low extent of the enolic form $(\sim 5-10 \%)$ in $\mathrm{CDCl}_{3}$-based solution [53].

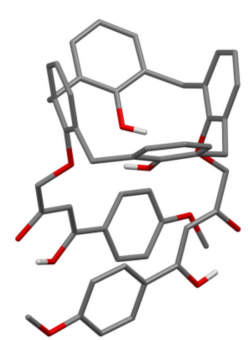

(a)

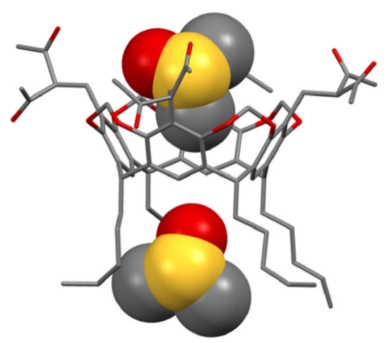

(b)

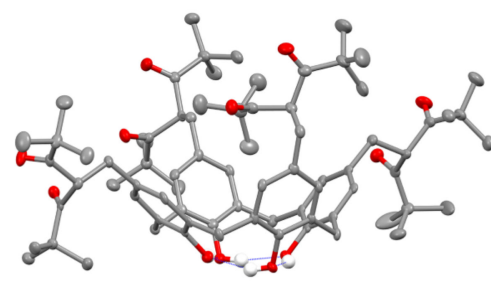

(c)

Figure 1. The molecules 19e (a), 26 (b)and 27b (c) in the crystal. Molecule of 26 (b) with two DMSO molecules is represented in space-filled model. Hydrogen atoms are omitted for clarity. Redrawn from reference [49] (a). Reproduced from Ref. [53] (b) and [58] (c) with permission from the Centre National de la Recherche Scientifique (CNRS), the Royal Society of Chemistry and the Elsevier, correspondingly.

The embedding of two or four 1,3-diketo-groups onto the upper rim of calix[4]arene is followed by the interference between the different tautomeric forms. For example, ketoketo $(50 \%)$, keto-enol $(30 \%)$ and enol-enol $(20 \%)$ are revealed in solutions of bis-1,3-diketone calix[4]arene 37 [55]. It is also worth noting the specificity of keto-enol tautomerism for 1,3-diketo-groups embedded onto the calix[4]arene platform. This is well exemplified by the decreased extent of enol form $(<0.2 \%)$ under the substitution of methyl groups on phenyl or $t$-Bu ones in the $\beta$-position [55] (Table 1), since the keto-enol transformation is restricted by the steric hindrance illustrated by the structure of $\mathbf{2 7 b}$ in Figure $1 \mathrm{c}$. 


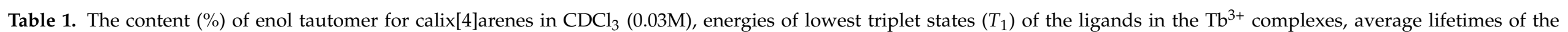

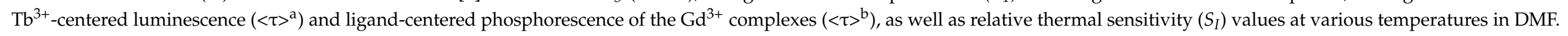

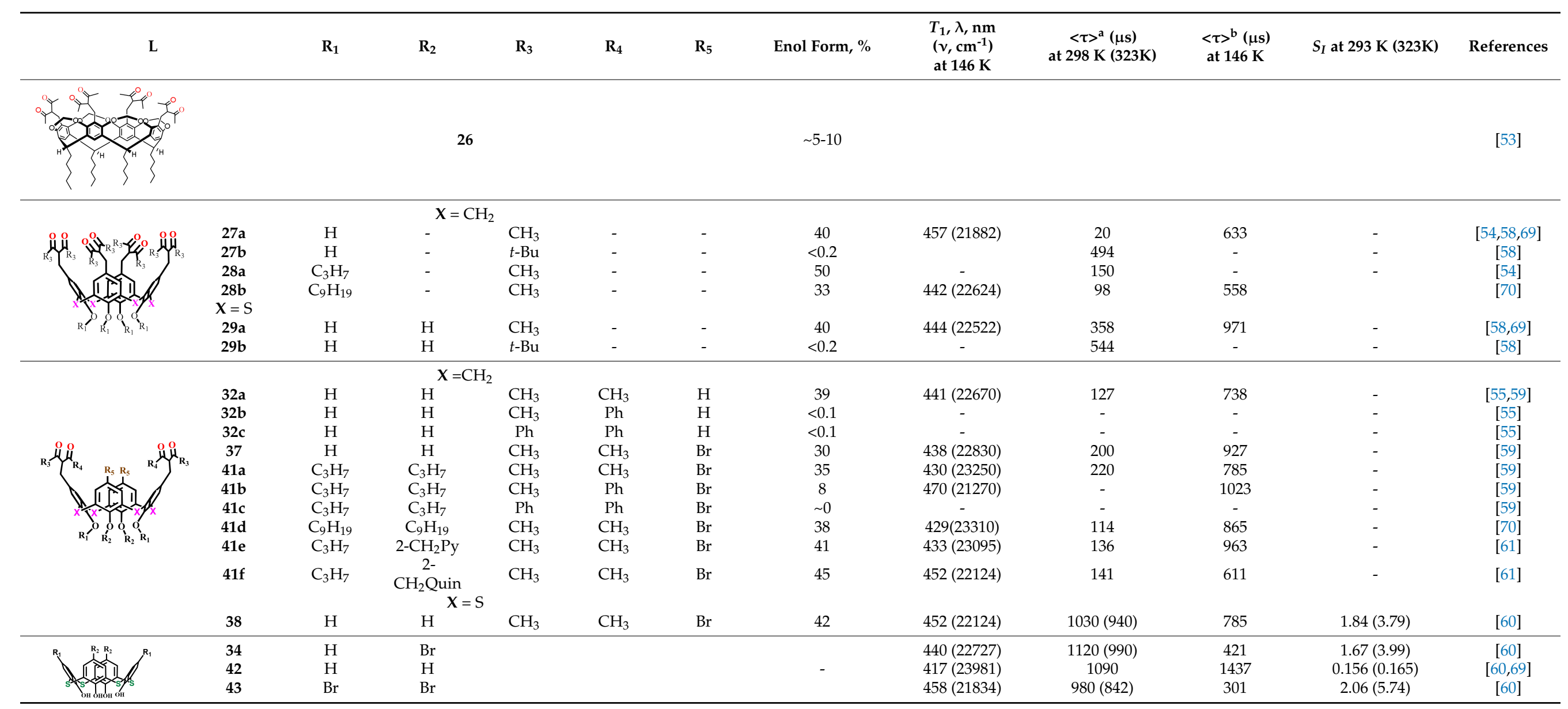




\section{Complex Formation of 1,3-Diketone Calix[4]arene Derivatives with Metal Ions}

The enolic form derived from the keto-enol transformation in alkaline media can form carbanions or enolates, while the latter can be stabilized by the complex formation with metal ions (Scheme 11). The presence of the pre-organized donor oxygen atoms of enolate form provides the efficient chelating of both $d$ - and $f$-transition metal ions [23]. The complex formation of the commonly applied 1,3-diketones results in the formation of tris-chelates, which saturate the coordination sphere of $d$-transition metal ions, while the high coordination numbers of lanthanide ions provide the reason for remaining one or two coordination sites unoccupied under their tris-chelation with 1,3-diketonates [23]. The combination of two or greater number of 1,3-diketone moieties within one molecule restricts their abilities to tris-chelation, thus, raising the necessity to ternary complex formation [25], which makes such complexes promising basis for a substrate-induced luminescent answer.

The various ways of embedding of 1,3-diketone moieties onto calix[4]arene backbone are schematically illustrated in Figure 2. It is obvious that the embedding mode of 1,3diketo-groups is of great impact on their ability to coordinate metal ions through the bis-chelation, since the latter results in more tight metal ion coordination than a monochelation by single 1,3-diketonate group. It is worth anticipating that a bis-chelation of metal ions by rigidly oriented 1,3-diketone groups in structures $\mathbf{1 6 a}, \mathbf{b}$ can be realized only in sandwich-like dimeric metal complexes, while the embedding of the 1,3-diketone-groups via methylene bridge onto calix[4]arene (structure 2 in Figure 2) facilitates their ability to both intramolecular and intermolecular chelating of metal ions. However, literature data on the complex formation of calix[4]arene derivative $\mathbf{2}$ with metal ions is exemplified by copper ions only, where the sandwich-like 2:2 complexes based on the bis-chelation of $\mathrm{Cu}^{2+}$ ions with 1,3-diketonate groups of two calix[4]arene ligands has been revealed [42].

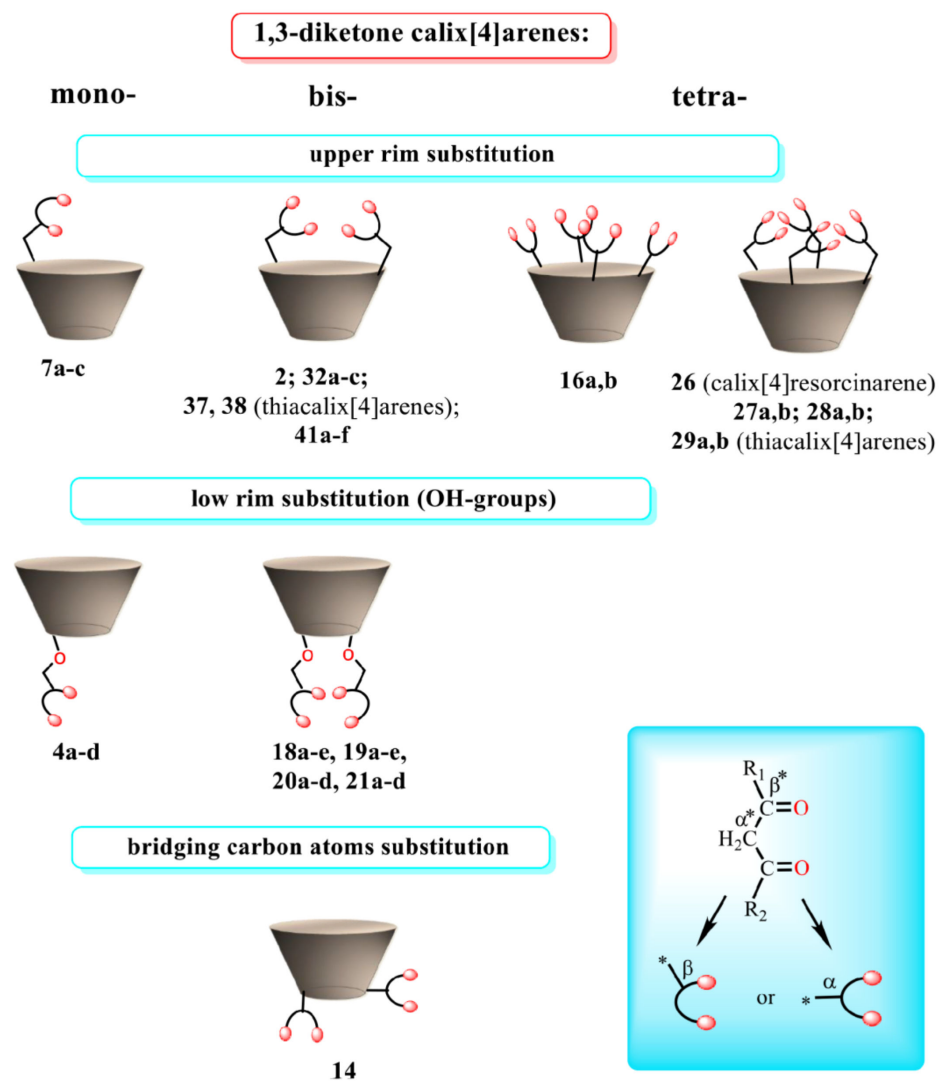

Figure 2. Schematic presentation of 1,3-diketone calix[4]arenes with different embedding modes of 1,3-diketone groups onto cyclophanic backbone. 
It is worth assuming that 1,3-diketonate groups of the calix[4]arenes upper-rim substituted by both two and four 1,3-diketone groups $27 \mathbf{a}, \mathbf{b}, \mathbf{2 8} \mathbf{a}, \mathbf{b}, \mathbf{3 2} \mathbf{a}-\mathbf{c}$ and $\mathbf{4 1} \mathbf{a}-\mathbf{f}$ can provide only 1:1 bis-chelation of metal ions. The assumption has been proved by both experimental results and quantum-chemical calculations $[54,55,69]$. The bis-chelation of terbium ions by 1,3-diketonates is more thermodynamically favorable than their coordination with the lower phenolic/phenolate rim of both tetra- (27a) [54] and bis-acetylacetone-substituted calix[4]arenes 32a, $37[55,59]$ as it is illustrated by Figure 3 . Thus, the presence of the lower phenolic rim doesn't affect the coordination of $\mathrm{Tb}^{3+}$ ion with 1,3-diketonates embedded at the upper rim of calix[4]arene backbone [54,55].

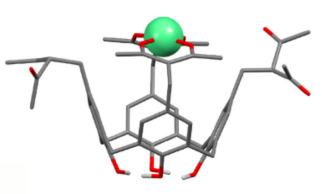

(a)

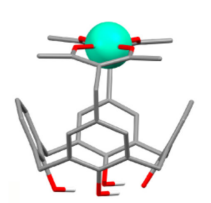

(b)

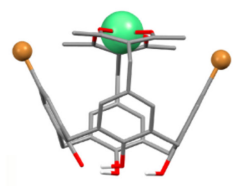

(c)

Figure 3. Bis-chelated coordination of $\mathrm{Tb}^{3+}$ ion by tetra-1,3-diketone 27a (a) and bis-1,3-diketone 32a (b) and 37 (c) calix[4]arenes. The structures are obtained after SPARKLE/PM7 optimization with the use of MOPAC 2012 software. Reproduced from Ref. [54] (a), [59] (c) and redrawn from reference [55] (b) with permission from the Elsevier, the Centre National de la Recherche Scientifique (CNRS) and the Royal Society of Chemistry.

The opposite tendency is observed for its thia-analogue $[58,60,69]$. The complexing capacity of the lower thiacalix[4]arene's phenolic rim is much higher than that of its classical counterpart [71-73]. This makes the coordination of $\mathrm{Tb}^{3+}$ ion via lower thiacalix[4]arene's phenolic rim more thermodynamically favored than its bis-chelation with two diketonate groups [69]. The lower rim coordination is enforced by the dimerization of the $1: 1 \mathrm{com}-$ plexes in accordance with Figure 4 which illustrates the coordination modes of $\mathrm{Tb}^{3+}$ ions with dibromo-bis-1,3-diketone thiacalix[4]arene 38. The similar coordination is observed for the tetra-1,3-diketone thiacalix [4]arenes 29a. However, the comparative analysis of both steady state and time resolved luminescence of terbium complexes with thiacalix[4]arene and its 1,3-diketone derivative in DMF indicates that the bis-chelation via the upper rim contributes to the complex formation $[60,69]$.

As it has been already noted the benzoylacetone moieties embedded onto calix[4]arene platform exhibit the restricted keto-enol transformation [59]. Thus, the complex formation of the calix[4]arenes bearing benzoylacetone moieties (32a-c in Scheme 9) with terbium ions is slowed down and comes to the equilibrium conditions within one day, while the complex formation extent is still insignificant within one day for the diphenyl substituted 1,3-diketone derivatives Figure 5 [55]. This tendency differs from the common 1,3-diketones, where $\beta$-carbon phenyl-substitution results in the additional stabilization of the enol form through the coupling of diketonate ring with the aromatic substituents. 


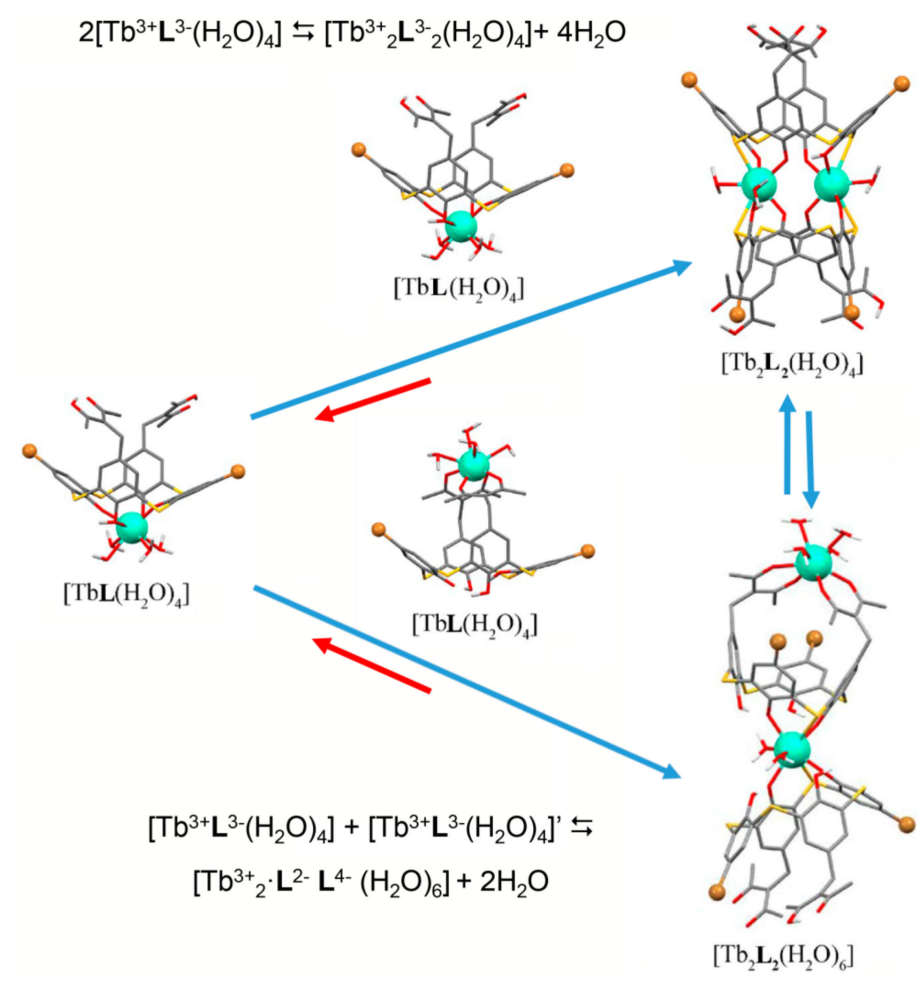

Figure 4. Schematic presentation of the equilibration between monomeric complexes $\left[\mathrm{TbL}\left(\mathrm{H}_{2} \mathrm{O}\right)_{4}\right]$ and dimeric complexes $\left[\mathrm{Tb}_{2} \mathbf{L}_{2}\left(\mathrm{H}_{2} \mathrm{O}\right)_{4}\right]$ and $\left[\mathrm{Tb}_{2} \mathbf{L}_{2}\left(\mathrm{H}_{2} \mathrm{O}\right)_{6}\right](\mathbf{L}=38)$ in the DMF solutions.

fast
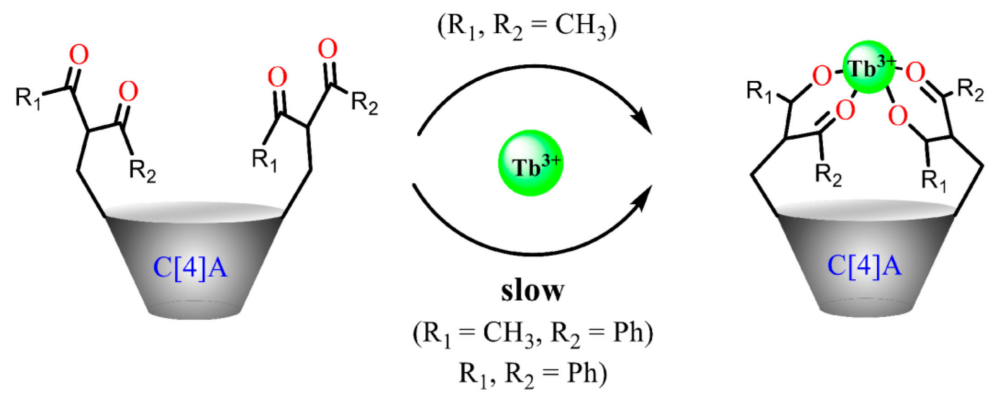

Figure 5. Cartoon illustration of the substituents effect on the complex formation of 1,3-diketone calix[4]arenes with $\mathrm{Tb}^{3+}$ Reproduced from Ref. [55] with permission from the Elsevier, the Centre National de la Recherche Scientifique (CNRS) and the Royal Society of Chemistry.

The embedding of 1,3-diketone moieties onto rigid structure of the calix[4]resorcinarene cavitand through the $\alpha$-carbon substitution results in greater effect on keto-enol transformation than the embedding onto calix[4]arene or thiacalix[4]arene backbones. The upper rim of the cavitand is wider than that of calix[4]arene, which provides the opportunity of the binding of two lanthanide ions through the bis-chelation with 1,3-diketonate groups of calix [4]resorcinarene cavitand. However, the formation of the thermodynamically more stable 2:1 complex (Figure $6 \mathrm{~d}$ ) is kinetically retarded and undergoes through the 1:1 complex formation (Figure 6a-c) [53]. 


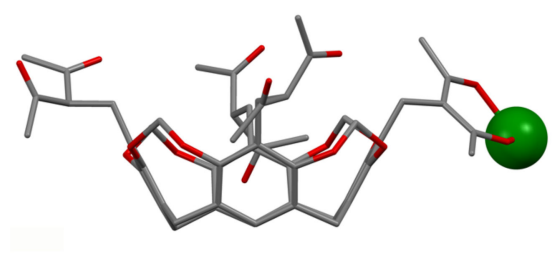

(a)

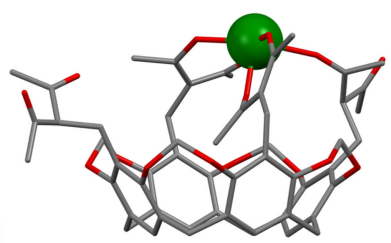

(c)

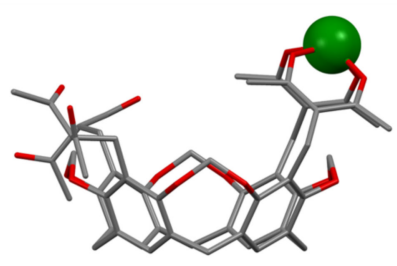

(b)

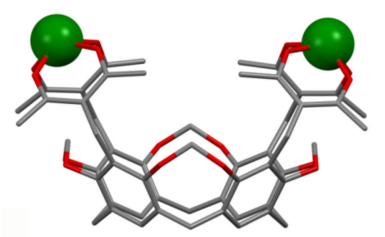

(d)

Figure 6. Possible modes of binding of $\mathrm{Tb}^{3+}$ cations to molecule 26 with participation of one (a), two (b), three (c) and four (d) 1,3-diketone groups (lower rim alkyl substituents are omitted)The structures are obtained after PM6 optimization of starting structures built on the basis of single-crystal X-ray data for molecule 26. Reproduced from Ref. [53] with permission from the Centre National de la Recherche Scientifique (CNRS) and the Royal Society of Chemistry.

\section{Lanthanide-Centered Luminescence Sensitized by the Cyclophanic 1,3-Diketones}

The peculiarity of a lanthanide-centered luminescence derives from the fact that the radiation decay occurs from the singlet excited state, which is mainly fed by ligand-tometal energy transfer, although the energy of the excited state is independent on the ligand environment [74]. Thus, design of optimal ligands providing efficient antenna-effect on lanthanide-centered luminescence should be based on tuning of ligand-centered triplet level for the optimal ligand-to-metal energy transfer.

The structure variation of the substituents neighboring to the diketo-group is the well-known tool for the triplet level energy optimization. This is well exemplified [23] by the series of 1,3-diketones, where substitution of methyl substituents on benzyl or thenoyl moieties modifies the triplet level, which, in turn, enables to sensitize the green or red luminescence of $\mathrm{Tb}^{3+}$ or $\mathrm{Eu}^{3+}$. The similar effect of substituents has been revealed for the differently substituted 1,3-diketone derivatives of calix[4]arenes (32a-c [55], 41a-c [59] on Table 1). In particular, the lower energy of the triplet level of the benzoylacetonesubstituted calix[4]arenes $(\mathbf{3 2} \mathbf{b}, \mathbf{4 1} \mathbf{b})$ versus the acetylacetone-substituted ones $(\mathbf{3 2} \mathbf{a}, \mathbf{3 7}$, $41 a, d)$ is the reason for the different antenna effects on the $\mathrm{Tb}^{3+}$-and $\mathrm{Yb}^{3+}$-centered luminescence. It is worth noting that the benzoylacetone-substituted ligand in greater extent than its acetylacetone-substituted counterpart sensitizes the NIR luminescence of $\mathrm{Yb}^{3+}$, while the acetylacetone-substituted ligand is better antenna for $\mathrm{Tb}^{3+}$-luminescence than its benzoylacetone-substituted counterpart [55]. However, the complex formation of benzoylacetone-substituted calix[4]arene with $\mathrm{Ln}^{3+}$ ions is greatly retarded due to the above mentioned effect of the $\alpha$-carbon substituents on the keto-enol tautomeric equilibrium of the 1,3-diketone derivatives of calix[4]arenes. This, in turn, restricts the antenna-effect of benzoylacetone- or dibenzoylmethane-substituted calix[4]arenes on the $\mathrm{Ln}^{3+}$-centered luminescence.

The energy stock from the excited state through the radiationless decay is the wellknown reason for quenching of lanthanide-centered luminescence. Thus, the restricted vibrational movement of the inner-sphere ligands lowers the radiationless decay contribution. The fluorination or bromination of methyl or phenyl moieties is the well-known prerequisite for rigidifying of the inner-sphere environment of lanthanide ions $[23,35,75]$. 
The upper-rim bromination of 1,3-diketone derivatives of calix[4]arene (37, 41a-f) decreases the radiationless decay, which exemplifies the so-called heavy atom effect [59] (Figure 7a).

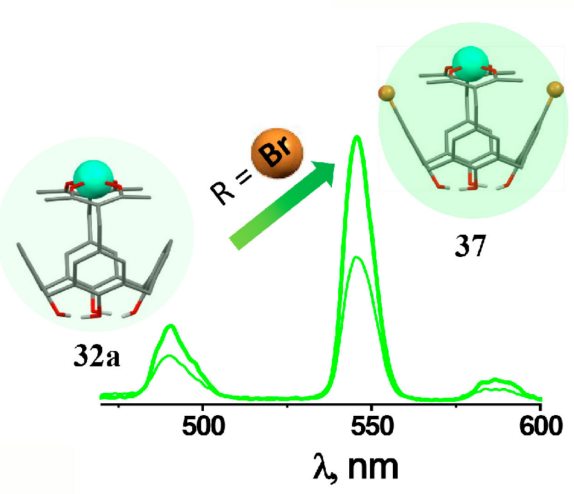

(a)

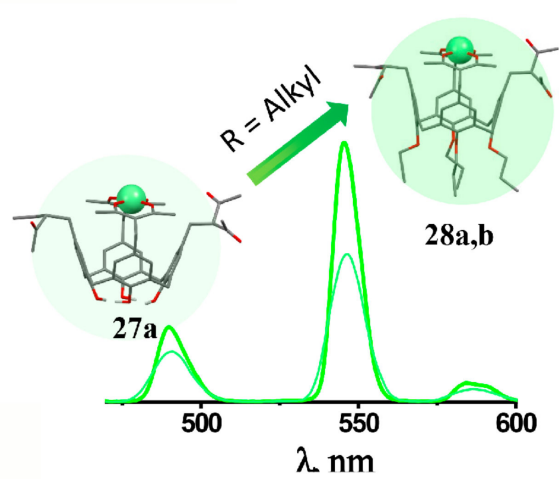

(b)

Figure 7. Cartoon illustration of the effect of lower rim (a)and upper rim (b) substituents on the $\mathrm{Tb}^{3+}$ centered luminescence of $\left[\mathrm{Tb}^{3+} \mathrm{L}\right]$ complexes with differently substituted 1,3-diketone calix[4]arenes. Reproduced from Ref. [59] (a) with permission from the Elsevier.

It is worth assuming that the pre-organization of the chelating groups at the cyclophanic backbone is one more prerequisite for rigidifying of the inner-sphere environment of lanthanide ions. This is manifested by the great values of the excited state lifetime values measured for the 1:1 terbium complexes, although the hydration number (q) is above 4 , which is higher than for terbium tris-acetylacetonate $(\mathrm{q}=2)[35,36]$. The aforesaid is worth correlating with the rigid inner-sphere environment resulted from the chelation of $\mathrm{Tb}^{3+}$ ion via two diketonate groups embedded onto the calix[4]arene platform. Moreover, the lower rim functionalization exemplified by the alkoxy-substitution of the lower rim hydroxyls (27a, 28a,b) enhances both $\mathrm{Tb}^{3+}$ - and $\mathrm{Yb}^{3+}$-centered luminescence (Figure 7b) [54]. The tendency derives from the conformation flexibility of the non-substituted calix[4]arene due to disturbance of the intramolecular hydrogen bonding at the phenolic/phenolate rim, in turn, resulted from its deprotonation in the basified conditions required for the diketone-to-diketonate transformation, while the alkoxy-substituents restrict the conformation flexibility.

It is worth noting the different effects of the bis-bromination of 1,3-diketone cyclophanic derivatives based on calix[4]arene and thiacalix[4]arene platforms on their ability to sensitize the $\mathrm{Tb}^{3+}$-centered luminescence $[59,60]$. As it has been mentioned above, the dibromination of calix[4] arene scaffold (37) enables to sensitize the $\mathrm{Tb}^{3+}$-centered luminescence due to the so-called "heavy atom effect" decreasing the radiationless decay through rigidifying of intramolecular vibration and stretching movements. The bis-bromination of the 1,3-diketone thiacalix[4]arene (38) results in the quenching of the steady-state luminescence of its $\mathrm{Tb}^{3+}$ complexes, while it leads to the insignificant effect on the excited state lifetime of the luminescence (Table 1).

The difference in the coordination modes of $\mathrm{Tb}^{3+}$ in the complexes with 1,3-diketone calix[4]arene and its thia-analogue explains the aforesaid difference (Figures 3 and 4). Indeed, in the case of thiacalix[4]arene ligands the Br-substituents affect the triplet level energy (Table 1) [60], since the inductive and resonance effect of the substituents influence the ability of the ligand to feed the $f$-centered excited state through the Dexter mechanism. The decreased gap between the feeding and excited energy levels facilitates the back energy transfer, which, in turn, restricts the antenna effect of the thialix[4]arene ligand bearing the Br-substituents in comparison with the luminescence of the non-substituted counterpart.

The steady state luminescence intensity tends to linear decrease under the heating within the physiological temperature range $\left(20-50{ }^{\circ} \mathrm{C}\right)$ for the dimeric $\mathrm{Tb}^{3+}$ complexes 
with dibromo- (34 and 38) and tetra-bromo-substituted (43) thiacalix[4]arenes, while the insignificant temperature-induced quenching is revealed for the isostructural complexes with the non-substituted thiacalix[4]arene 42 (Figure 8). The quenching extent is up to $50 \%$ for the complexes with dibromo- and tetrabromo-substituted counterparts, and the relative thermal sensitivity $S_{I}$ (Table 1 ) values are greater than similar values documented in literature [32,76-79] for the terbium complexes with another ligands. Thus, the terbium complexes with the bromo-substituted thiacalix[4]arenes provide a good basis for developing of molecular thermometers.

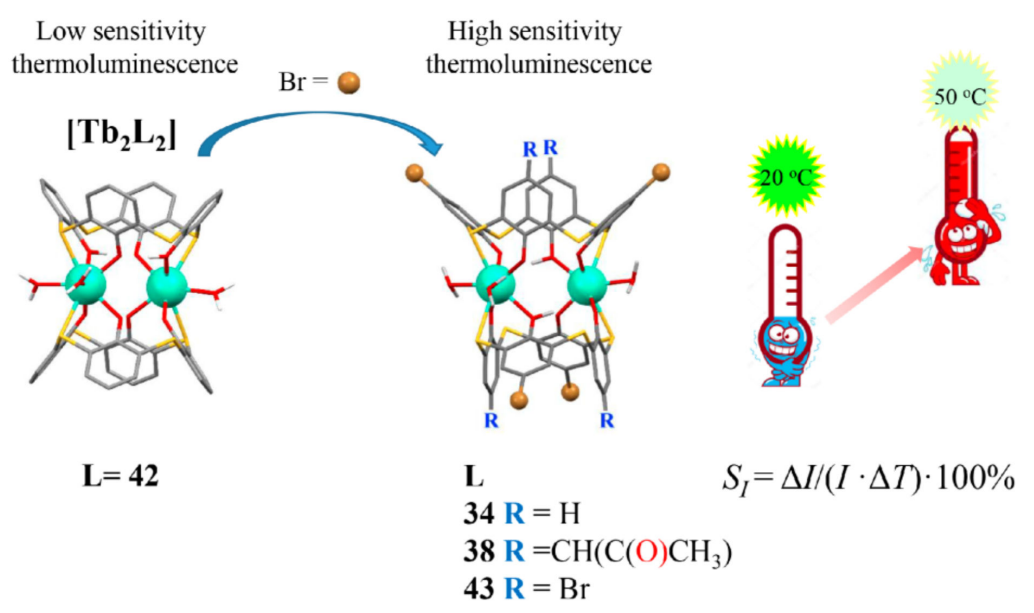

Figure 8. Cartoon illustration of the impact of the bromo-substitution on the thermal sensitivity of $\mathrm{Tb}^{3+}$-centered luminescence for dimeric complexes with the thiacalix[4]arene derivatives Redrawn from reference [60] with permission from the Royal Society of Chemistry.

It is also worth noting that high coordination number of the terbium complexes is the prerequisite for further ternary complex formation with chelating substrates resulting in the luminescence answer [37], although the poor water solubility of the complexes restricts their applicability in sensing. Moreover, the embedding of pyridyl or quinolyl groups at the lower rim of calix[4]arene bearing 1,3-diketone groups at the upper one provides the basis for heterometallic complex formation with $\mathrm{Tb}^{3+}$ ions bis-chelated by $\beta$-diketonates at the upper and copper ions coordinated with $\mathrm{N}$-donor atoms at the lower rims of calix[4]arene $(41 e, f)[61]$. The lower rim coordination of copper ions is followed by the quenching of $\mathrm{Ln}^{3+-}$ centered luminescence through the donor-acceptor energy transfer mechanism [80,81]. However, the potential of the developed terbium complexes in sensing can be highlighted only after their transformation into water dispersible nanoparticulate form.

\section{Nanoparticulate Forms of Cyclophanic 1,3-Diketonate Complexes for Sensing and Imaging}

The transformation of 1,3-diketonate lanthanide complexes into water dispersible forms is the well-known prerequisite for their applicability in sensing and imaging. The transformation can be achieved through different synthetic modes, which are discussed herein from a viewpoint of their usability for conversion of the lanthanide complexes with cyclophanic 1,3-diketonates into water dispersible nanoparticulate forms. The doping of the complexes into polymeric water dispersible nanoparticles commonly undergoes through the blending of the complexes with monomers followed by the stimuli-triggered polymerization. This route is convenient for embedding of 1,3-diketonate lanthanide complexes into polymeric films and nanoparticles [28,82-84].

Transparent, non-toxic and hydrophilic silica nanoparticles (SNs) are of greater impact on sensing and imaging among other polymeric nanoparticles $[85,86]$. However, conditions of alkaline- or acid-catalyzed hydrolysis of tetraethoxysilane are unfavorable for safe 
doping of 1,3-diketonate lanthanide complexes into silica matrix due to hydrolysis of lanthanide ions $[28,81]$. The aforesaid problem can be overcome by enhancing of the thermodynamic stability of the lanthanide complexes [87-90]. In the case of the tris1,3-diketonates the stability of their lanthanide complexes can be greatly enhanced by means of the ternary complex formation with $\mathrm{N}$-heterocyclic compounds or phosphine oxides. It is worth discussing the work of Wang group [91], since it demonstrates the safe inclusion of the $\mathrm{Tb}^{3+}$ complexes with DPA (shown in Figure 9) into silica seeds with further silica coating through the alkaline-catalyzed hydrolysis of tetraethoxysilane (TEOS). The synthetic scheme in Figure 9 also shows the embedding of $\mathrm{Eu}^{3+}$ complexes onto silica surface as the prerequisite for the sensing function of the Tb-Eu-silica nanoparticles, which, in turn, derives from the substrate-induced ternary complex formation. The doping of $\mathrm{Eu}^{3+}$ complexes in the form of the heterometallic Eu-Ir nanostructures is also the route for increasing the complex stability [92].

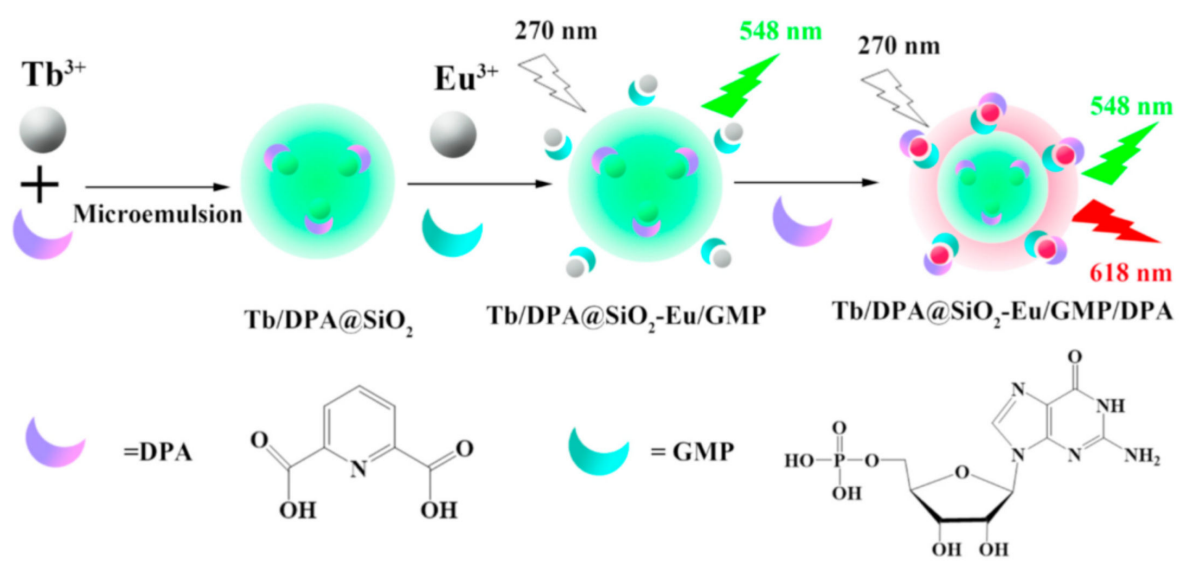

Figure 9. Schematic representation of $\mathrm{Tb}^{3+} / \mathrm{DPA} @ \mathrm{SiO}_{2}-\mathrm{Eu}^{3+} / \mathrm{GMP}$ (Guanosine 5'-monophosphate disodium salt) fluorescent probe formation. DPA, dipicolinic acid. Reproduced from Ref. [91] with permission from the Elsevier.

The covalent functionalization of 1,3-diketonate lanthanide complexes onto silica surface is also well documented as the route for their embedding onto SNs [93,94]. However, search for facile and easy synthetic route for safe conversion of 1,3-diketonate lanthanide complexes into nanoparticulate form is still challenging task. The nanoprecipitation route is widely applied for transformation of different lanthanide complexes into nanoparticles $[95,96]$. This method can be based on generation of the nano-aggregates from water soluble molecules and ions as it is shown in Figure 10 [97]. 

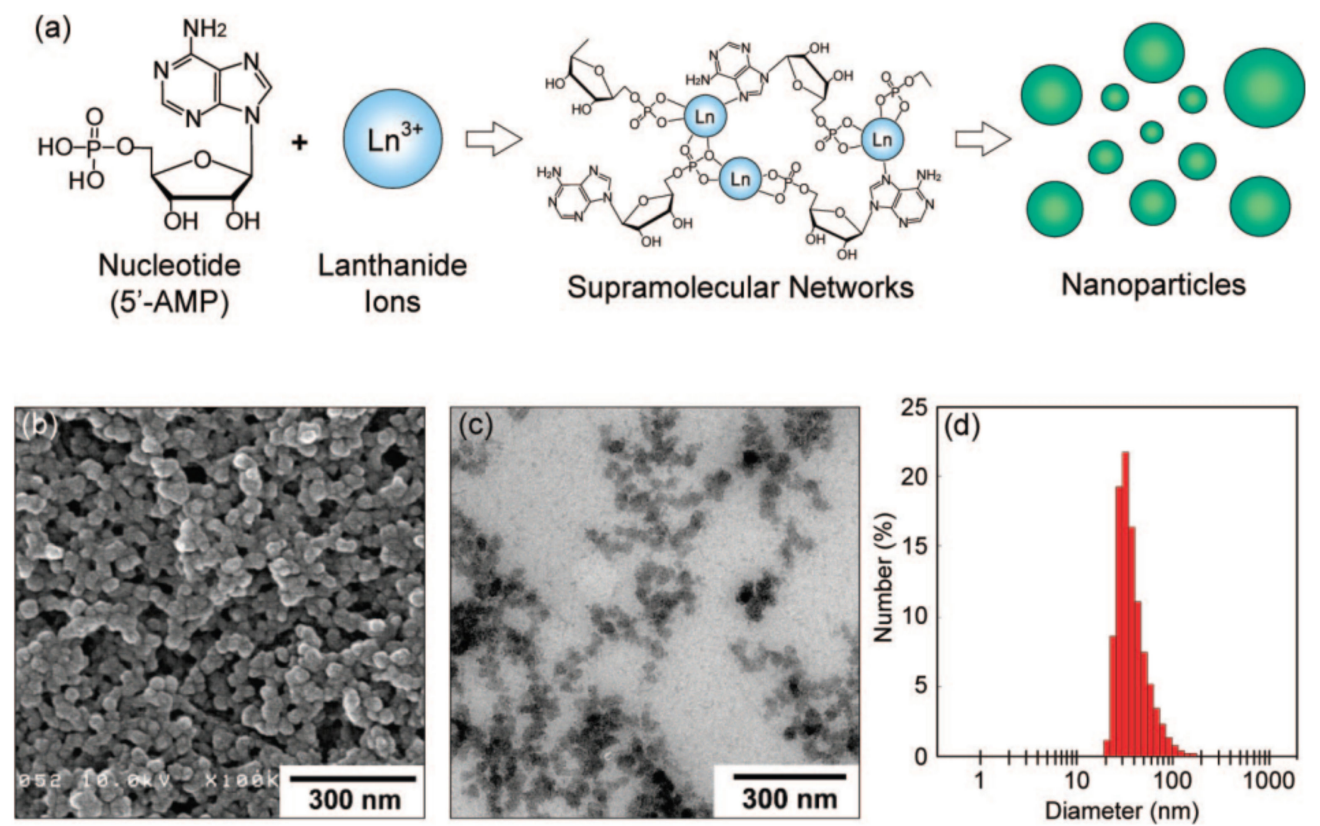

Figure 10. (a) A schematic illustration of nanoparticle formation through the self-assembly of $5^{\prime}$ AMP (5'-adenosinemonophosphate) and $\mathrm{Gd}^{3+}$ ions. (b) SEM image of $5^{\prime}$-AMP $/ \mathrm{Gd}^{3+}$ nanoparticles prepared in water. (c) TEM image of $5^{\prime}-\mathrm{AMP} / \mathrm{Gd}^{3+}$ nanoparticles dispersed in aqueous poly(sodium 4-styrene sulfonate). (d) Size distribution histogram obtained by dynamic light scattering (DLS) measurement. Reproduced from Ref. [97] with permission from the American Chemical Society.

The nanoprecipitation of the water insoluble lanthanide complexes with 1,3-diketonates can be performed through the modified solvent-exchange procedure [98]. The procedure is based on both nanoprecipitation of the complexes in the aqueous solutions of polyelectrolytes and adsorption of the latter at the nanoprecipitates (Figure 11). The adsorption of polyelectrolytes forms an exterior layer of the nanoprecipitates, which, in turn, provides their colloid stabilization. The latter was applied for transformation of $\mathrm{Eu}^{3+}$ complexes (exemplified by $\mathrm{TTA}^{-}$, which is thenoyltrifluoroacetonate) into water dispersible nanoparticulate form [81,99-101]. However, the coated by polystyrenesulfonate (PSS) $\mathrm{Eu}(\mathrm{TTA})_{3}$-based cores suffers from instability under the $\mathrm{pH}$ values above 8.0 or below 6.0. The stability of the $\mathrm{Eu}(\mathrm{TTA})_{3}$-based colloids can be greatly increased by means of the ternary complex formation with phosphine oxide derivatives (PhO) [101,102]. The procedure provides very good alternate to other synthetic routes for doping or deposition of lanthanide complexes into or onto silica nanoparticles. The advantage of the polyelectrolyte-coated morphology is the layer-by-layer polyelectrolyte deposition driven by an electrostatic attraction. In particular, the positively charged nanoprecipitates favor the adsorption of negatively charged PSS, while the negatively charged PSS exterior layer is the prerequisite for the adsorption of polyethyleneimine (PEI), which can be followed by the PSS-layer [101].

The presence of anionic groups in the exterior polyelectrolyte layer also provides the route for inclusion of the lanthanide ions. The incorporation of $\mathrm{Ln}^{3+}$ ions into the polyelectrolyte layer has been exemplified by either coordination of $\mathrm{Tb}^{3+}$ ions with carboxylates of polyacrylic acid [103] or encapsulation of $\mathrm{Eu}^{3+}$ 1,3-diketonate complex into the polyelectrolyte layer through the charge-dipole interactions $[104,105]$. 


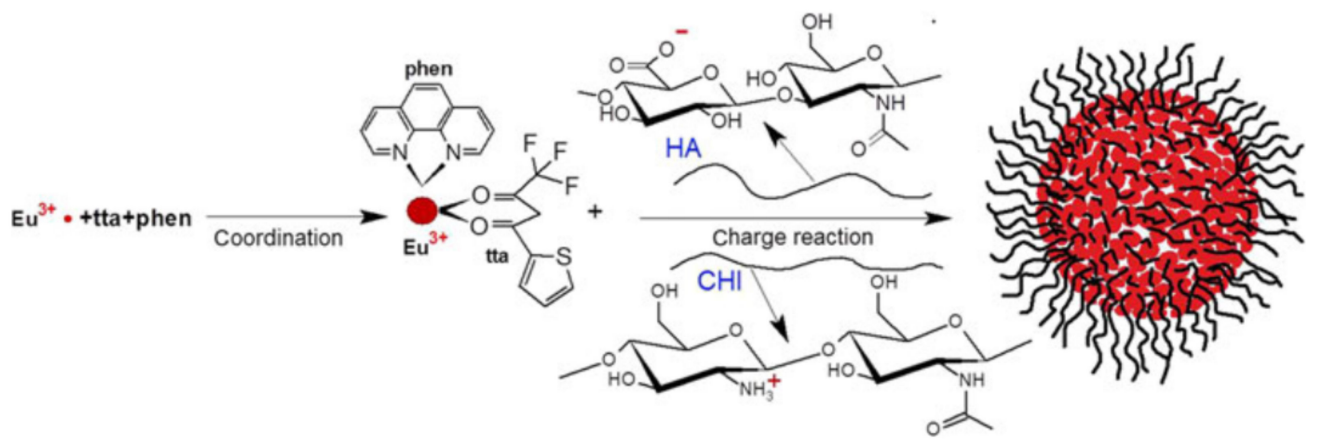

Figure 11. Formation of polyelectrolyte complexes containing $\mathrm{Eu}^{3+}$-tta-phen (phenantroline) and stabilized by hyaluronic acid and chitosan. Reproduced from Ref. [98] with permission from the Springer Nature.

As it has been mentioned above the embedding of 1,3-diketone moieties onto the cyclophanic backbone both favors the bis-chelation of lanthanides and facilitates the nanoprecipitation of the lanthanide complexes in the framework of the solvent-exchange-based synthetic route. This enables to convert the lanthanide complexes with the cyclophanic derivatives of 1,3-diketonates into water dispersible nanoparticles through the modified nanoprecipitation procedure as it is shown in Figure 12a.

a)

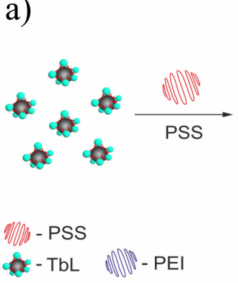

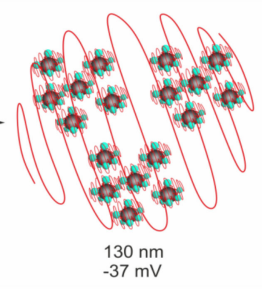

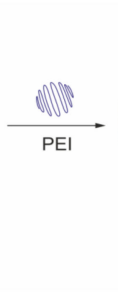

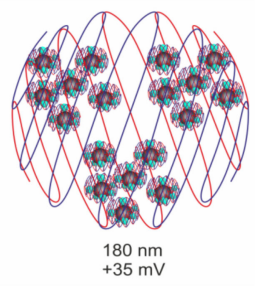

Figure 12. (a) Schematic illustration of nanoprecipitation method of nanoparticles formation. (b) Schematic illustration of two types of lanthanide-based blocks with different surface and bulk $\left[\mathrm{Eu}(\mathrm{TTA})_{3} \mathrm{PhO}\right.$ l localization. Reproduced from Refs. $[106,107]$ with permission from the Elsevier.

The nanoprecipitation of the lanthanide complexes results in two types of lanthanidebased building blocks with different inner- and outer-sphere environment, as it is schematically illustrated in Figure 12b. These two types of the lanthanide complexes are manifested by the two-exponential decay which, in turn, can be ascribed to the presence of different environments around the complexes. The latter may depend on position of the luminescent complexes inside or at the surface of the nanoparticles, where the presence of local defects and interface states may provide non-radiative recombination paths [106,108]. The specific bis-chelating coordination mode of lanthanide ions in the complexes with cyclophanic 1,3-diketonates provides greater stability than the mono-chelation of $\mathrm{TTA}^{-}$. This is manifested by the invariance of the lanthanide-centered luminescence of the PSS-coated nanoprecipitated terbium complexes with the cyclophanic 1,3-diketone derivatives which will be further designated as [TbL] ( $\mathrm{L}$ is cyclophanic 1,3-diketonate) at the $\mathrm{pH}$ values varied within wide $\mathrm{pH}$-range (4-9) [53]. The easy manipulation with the PSS-stabilized colloids through the centrifugation-induced phase separation and further re-dispersion in different solutions enables their re-usability, which, in turn, facilitates their applicability in sensing [53,61,101,106-115].

The high activity and coordinative unsaturation of the lanthanide centers located at the interfacial layer is the prerequisite for the sensing of antibiotics of fluoroquinolone and tetracycline series, where the ternary complex formation triggers the pronounced answer of the terbium-centered luminescence $[100,109]$. The embedding of the specific N-heterocyclic moieties onto lower rim of calix[4]arene bearing 1,3-diketone moieties at the upper rim 
(41f) provides the binding sites for both terbium and copper ions [61]. In turn, the $\mathrm{Cu}^{2+}$ $\mathrm{Tb}^{3+}$ heterometallic complex formation should be followed by the quenching of the $\mathrm{Tb}^{3+}$ centered luminescence (Figure 13a). The quenching effect is the basis for sensing of copper ions at very low concentration level. The quenching effect is contributed by both steady state and dynamic quenching mechanisms, in turn, derived from the ions exchange and donor-acceptor energy transfer correspondingly [61]. Moreover, the nature of the exterior layer exemplified by PEI provides the sensing of copper ions through the luminescence of [Eu(TTA) ${ }_{3} \mathrm{PhO}$-based colloids (PhO is the phosphine oxide derivative) [81]. The separation of copper and terbium ions due to their predominant localization in the exterior and interior zones of the $\mathrm{Eu}(\mathrm{TTA})_{3}$-based colloids coated by PSS-PEI bilayer is the prerequisite for the great contribution of the dynamic quenching mechanism (Figure 13a).

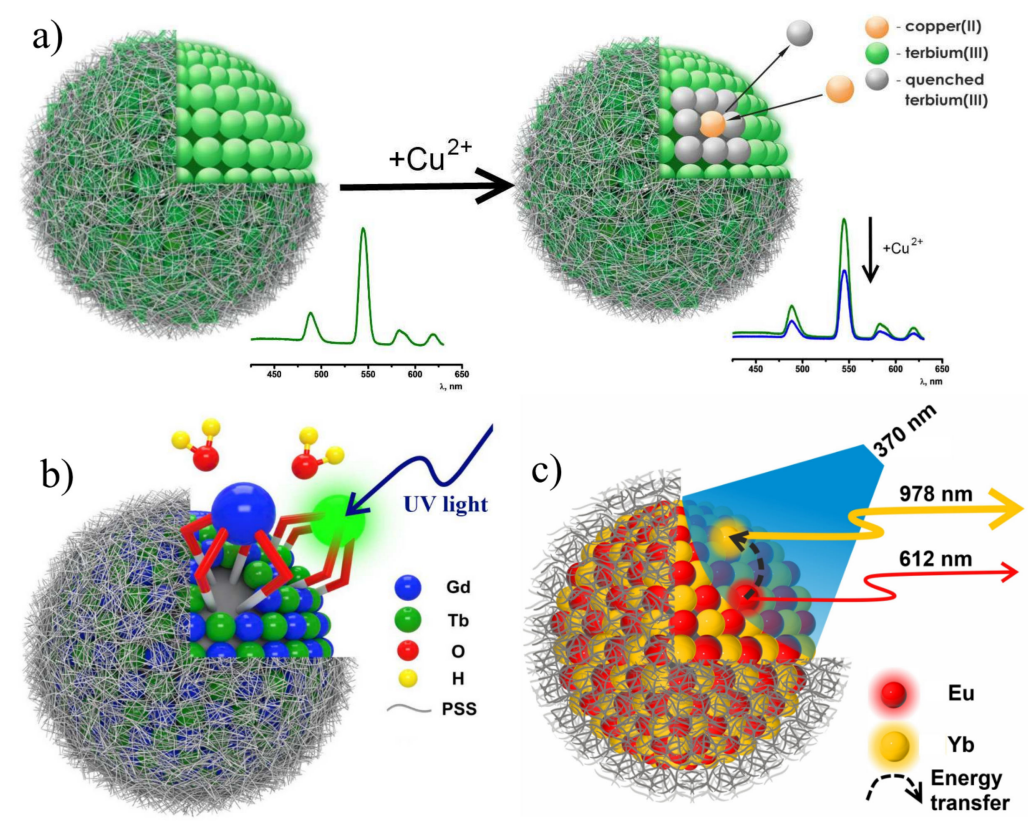

Figure 13. (a) Illustrative demonstration of $\mathrm{Tb}^{3+}$-centered luminescence quenching by copper(II) ions. (b) Schematic structure of heterometallic $\mathrm{Tb}^{3+}$ and $\mathrm{Gd}^{3+}$ PSS-coated nanoparticles. (c) Representation of $\mathrm{Eu} \rightarrow \mathrm{Yb}$ energy transfer in PSS-[Ln (TTA) 3 PhO] colloids. Reproduced from Refs. [61,106,108] with permission from the Springer Nature and the Elsevier.

The close similarity in the coordination properties of the neighboring lanthanide ions, exemplified by $\mathrm{Tb}^{3+}$ and $\mathrm{Gd}^{3+}$ makes their complexes with 1,3-diketone calix[4]arenes structurally similar (Figure 13b), which enables to evaluate the triplet level of the ligand from the ligand-centered luminescence of $\mathrm{Gd}^{3+}$ complexes with the cyclophanic 1,3-diketone (27a). The structural similarity also favors a combination of the $\mathrm{Tb}^{3+}$ and $\mathrm{Gd}^{3+}$ complexes within each nanoprecipitate when the complexes are mixed the DMF solution with further nanoprecipitation in the aqueous-DMF solution of PSS [108]. The combination of the $\mathrm{Tb}^{3+}$ - and $\mathrm{Gd}^{3+}$-counterparts enables to reveal the concentration-induced quenching of the $\mathrm{Tb}^{3+}$-centered luminescence. The similar effect was detected for $\mathrm{Eu}(\mathrm{TTA})_{3} \mathrm{PhO}$ complexes converted into the PSS-coated colloids under their dilution by the $\mathrm{Lu}^{3+}$ - and $\mathrm{Yb}^{3+}$-counterparts [106]. The difference in photophysical properties of homometallic and heterometallic colloids reveals the energy transfer between the lanthanide complexes constituting the nanoprecipitates. The latter is either restricted or enhanced under their self-assembly within heterometallic nanoparticles which, in turn, can be the reason for tuning their photo-physical properties. In particular, the concentration induced quenching in the homometallic nanoparticles with $\mathrm{Eu}^{3+}$-centered luminescence can be significantly decreased in the $\mathrm{Eu}^{3+}$ - $\mathrm{Lu}^{3+}$-based colloids derived from the self-assembly of luminescent $\mathrm{Eu}^{3+}$ and non-luminescent $\mathrm{Lu}^{3+}$ isostructural complexes. The quenching of $\mathrm{Eu}^{3+}$-centered lumi- 
nescence in the $\mathrm{Eu}^{3+}-\mathrm{Yb}^{3+}$ nanoparticles due to $\mathrm{Eu} \rightarrow \mathrm{Yb}$ energy transfer is accompanied by increase in the NIR luminescence of $\mathrm{Yb}^{3+}$ complexes (Figure 13c).

The conversions of the $\mathrm{Tb}^{3+}$ complexes with cyclophanic 1,3-diketonates into the PSSbased colloids makes them promising basis for the cellular imaging. The staining of the cell cytoplasm by the green luminescence of terbium complexes with 1,3-diketone calix[4]arene (28a) results from the cell internalization of their PSS-coated colloids [107]. It is worth noting that the negative charge of the PSS-based exterior layer of the colloids doesn't prevent their cell internalization, while the double-layered PEI-PSS-coated colloids with positively charged exterior layer exhibit worse cell internalization versus the PSS-coated colloids (Figure 14) [107]. This tendency is explained by the enhanced aggregation of the double layered colloids versus the mono layered ones. In turn, the cellular uptake behavior of the PSS-coated colloids in great extent derives from the so-called protein corona arisen from the interactions with the blood serum proteins in the cell samples (Figure 14a,b). The use of the $\left[\mathrm{Eu}(\mathrm{TTA})_{3} \mathrm{PhO}\right]$-based colloids enables to stain the cell cytoplasm by red Eu-centered luminescence [106].

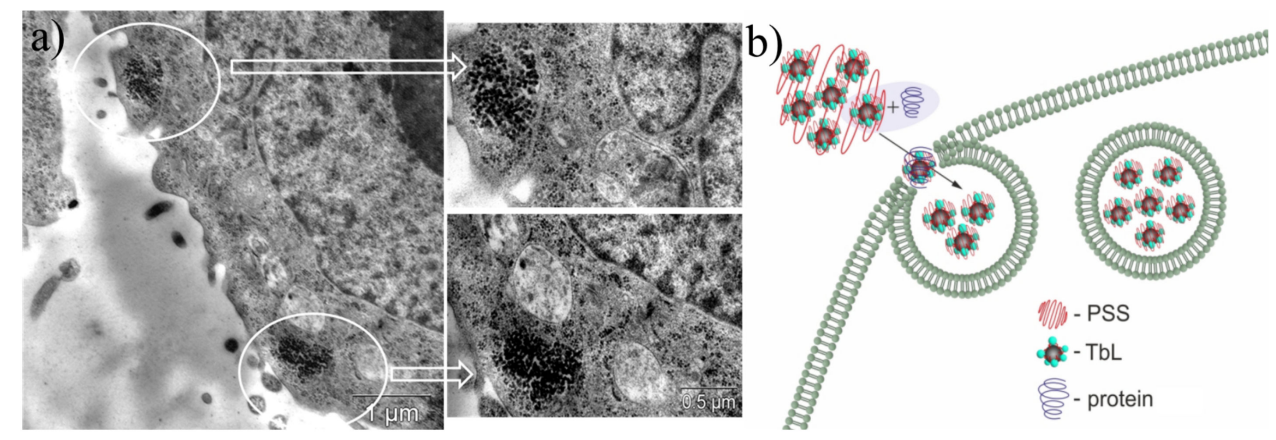

Figure 14. (a) TEM image of Hep-2 (human larynx carcinoma) cells incubated with PSS-[Tb28a] colloids. White circles designate the localization of the nanoparticles. (b) Schematic illustration of BSA (bovine serum albumin) assisted cell internalization of PSS-[Tb28a] colloids. Reproduced from Ref. [107] with permission from the Elsevier.

Our work [111] is worth mentioning as an example of sensing ability of the PSS-coated colloids based on the terbium dinuclear complexes with two thiacalix[4]arene ligands $\left(\left[\mathrm{Tb}_{2}(\mathrm{~L})_{2}\right]\right)(\mathrm{L}=34,43)$. As it has been mentioned above, the energy of the ligand's triplet energy in $\left[\mathrm{Tb}_{2}(\mathrm{~L})_{2}\right](\mathrm{L}=\mathbf{3 4}, 43)$ complexes facilitates the temperature-induced quenching resulted from the enhancement of the back energy transfer. The transformation of the dimeric complexes into the PSS-coated colloids prerequisites their intracellular localization, which, in turn, provides the applicability of PSS- $\left[\mathrm{Tb}_{2}(\mathrm{~L})_{2}\right](\mathrm{L}=34,43)$ nanoparticles as highly sensitive intracellular temperature nanosensors (Figure 15a-f).

The transmission electronic microscopy (TEM) analysis reveals that the average size of the nanoprecipitates is at the level of $4-12 \mathrm{~nm}[53,107,109,113]$. It is worth noting that such size level is favorable for high extent of the $\mathrm{Ln}^{3+}$ centers located at the water/nanoparticle interface [116]. The interfacial localization of the metal centers in the colloids facilitates their accessibility to water molecules from the bulk of solution. This fact along with the high hydration number of the $\mathrm{Ln}^{3+}$ complexes with 1,3-diketone calix[4]arenes is the reason for high longitudinal relaxivities of the colloids based on the $\mathrm{Gd}^{3+}$ complexes with calix[4]arene 1,3-diketonates [108,110]. This, in turn, is the prerequisite for efficient contrasting effect in NMR imaging [111]. The longitudinal and transverse relaxivity values $\left(\mathrm{r}_{1}\right.$ and $\left.\mathrm{r}_{2}\right)$ measured in the aqueous colloids of the PSS-coated colloids based on the $\mathrm{Gd}^{3+}$ complexes with the cyclophanic 1,3-diketones are within $14-20 \mathrm{mM}^{-1} \cdot \mathrm{s}^{-1}(\mathbf{2 6}, \mathbf{2 7 a})[108,110]$. These values are higher than those reported for the $\mathrm{Gd}^{3+}$-based commercial contrast agents [116] due to the slowed down rotational and translational motion of the Gd-centers after their transformation from molecular to nanoparticulate form. 

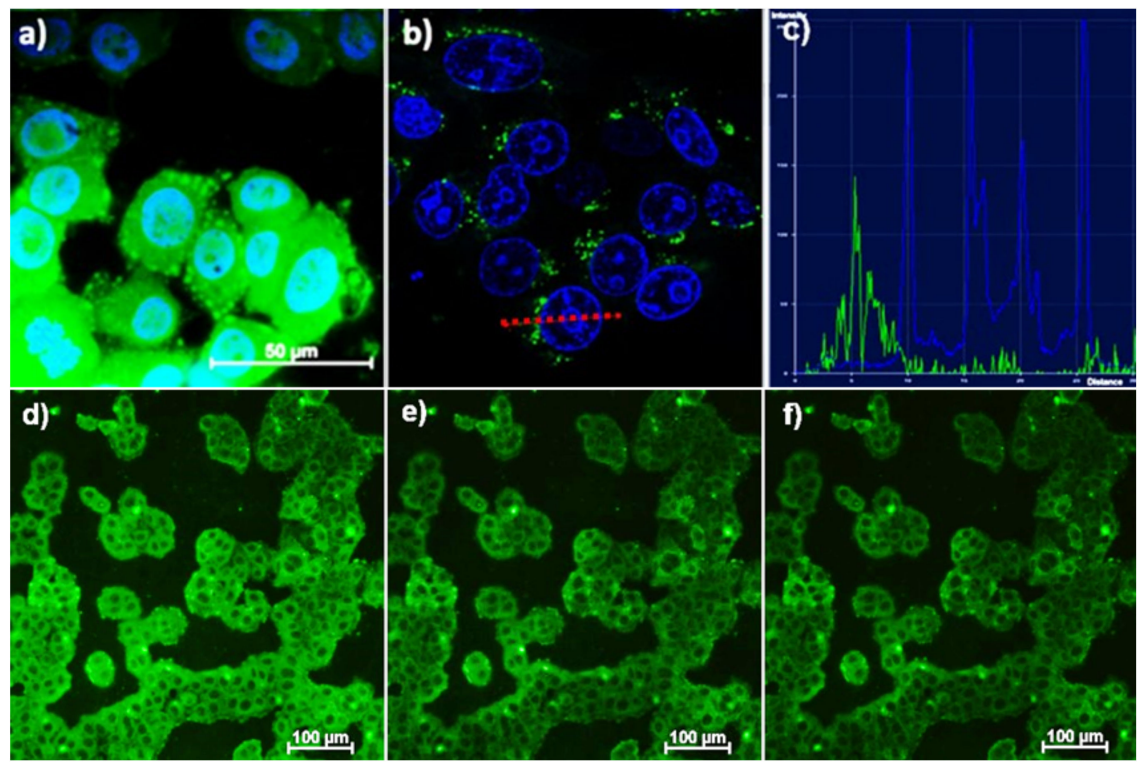

Figure 15. Fluorescent microscopy (a) and confocal microscopy (b) images of M-Hela cells incubated with PSS-[ $\left[\mathrm{Tb}_{2}(43)_{2}\right]$. The cell nuclei are stained by DAPI (a) and Hoechst $33342(\mathbf{b})$. The graph of luminescence intensity of Hoechst 33342 (blue) and nanoparticles (green) (c) between two points, designated on (b) with red line, demonstrating the nanoparticles location outside the cell's nu-

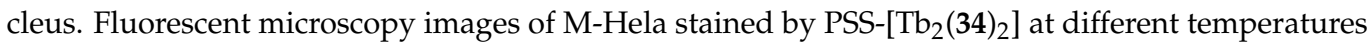
(d) $30^{\circ} \mathrm{C}$, (e) $35^{\circ} \mathrm{C},(\mathbf{f}) 40^{\circ} \mathrm{C}[114]$

As it has been mentioned above, the $\mathrm{Gd}^{3+}$ complexes with the cyclophanic 1,3-diketone derivatives are isostructural with the terbium ones, which facilitates the joint study of both $\mathrm{Tb}^{3+}$ - and $\mathrm{Gd}^{3+}$ counterparts. The latter, in turn, enables to evaluate the hydration number of the $\mathrm{Ln}^{3+}$ centers in the colloids by measuring of the time resolved $\mathrm{Tb}^{3+}$-luminescence in $\mathrm{H}_{2} \mathrm{O}$ and $\mathrm{D}_{2} \mathrm{O}$ solutions for highlighting an impact of the hydration number on the relaxivity values of the colloids [111,114]. The joint study of both $\mathrm{Tb}^{3+}$ - and $\mathrm{Gd}^{3+}$ counterparts of the PSS-coated colloids based on calix[4]arene 1,3-diketones (32a, 32b, 37) and thiacalix[4]arenes $(34,42)$ (Figure 16a,b) enabled to highlight the impact of the coordination modes of $\mathrm{Gd}^{3+}$ ions by the aforesaid ligands on both $\mathrm{Tb}^{3+}$-luminescence and $\mathrm{Gd}^{3+}$-induced paramagnetic enhancement of the water protons [111,114]. The low hydration number derived from the binuclear sandwich-like coordination of $\mathrm{Ln}^{3+}$ ions by two thiacalix[4]arenes $(\mathbf{3 4}, \mathbf{4 2})$ (Figure 16a) facilitates the $\mathrm{Tb}^{3+}$-luminescence of their colloids in comparison with those based on $\mathrm{Tb}^{3+}$ complexes with the cyclophanic 1,3-diketonates (32a, 32b, 37) (Figure 16b). However, the $r_{1}$ and $r_{2}$ values of the colloids based on $\mathrm{Gd}^{3+}$ counterparts with thiacalix[4]arene are lower $\left(1.8-2.6\right.$ and $\left.2.7-3.9 \mathrm{mM}^{-1} \mathrm{~s}^{-1}\right)$ than those measured for complexes with calix[4]arene 1,3-diketonates with the greater hydration number [111]. Moreover, the joint study of the isostructural $\mathrm{Tb}^{3+}$ and $\mathrm{Gd}^{3+}$ complexes with calix[4]resorcinarene 1,3-diketone as building blocks of the PSS-coated colloids facilitated to reveal the effect of their aggregation on $r_{1}$ and $r_{2}$ values [113]. In particular, the enhanced aggregation derived from the double layered (PEI-PSS) coating of the nanoprecipitates restricts the accessibility of the $\mathrm{Gd}^{3+}$-centers to water molecules, which is manifested by the decrease in the $r_{1}$ and $r_{2}$ values. In turn, these values tend to increase under the de-aggregation of the colloids induced by their interaction with the blood serum proteins (Figure 16c) [113]. 


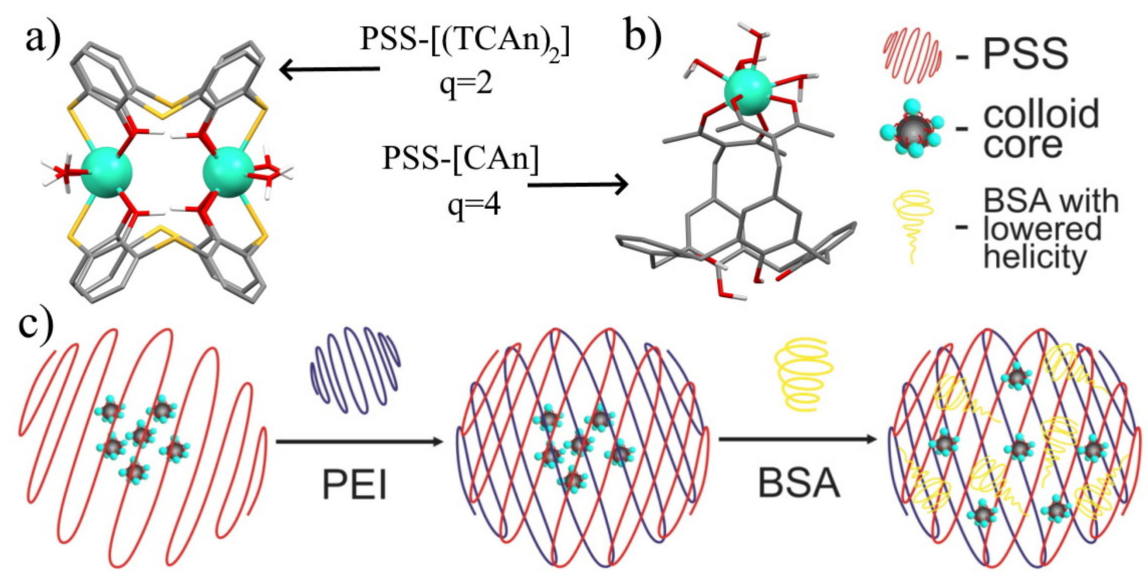

Figure 16. Schematic presentation of the coordination modes of $\mathrm{Ln}^{3+}$ ions in (a) $\left[\mathrm{Ln}_{2}(\mathrm{TCAi})_{2}\right.$ ] $(\mathrm{TCAi}=34,42)$ and $(\mathrm{b})$ [LnCAi] $(\mathrm{Cai}=32 \mathrm{a}, 32 \mathrm{~b}, 37)$ complexes and their corresponding hydration numbers, q. (c) Schematic presentation of PSS-Na[Gd 2 26], PEI-PSS-Na[Gd $\left.{ }_{2} 26\right]$, and BSA-PEI-PSS$\mathrm{Na}\left[\mathrm{Gd}_{2} 26\right]$ colloids. Reproduced from Refs. $[109,113]$ with permission from the Elsevier.

The great advantage of the calix[4]arene backbone is the ability to embed the functional groups for controlling the hydrophobicity or hydrophilicity of both lower and upper rims of calix[4]arene. The increased hydrophobicity of the calix[4]arene 1,3-diketones can be achieved through their lower rim substitution by nonyloxy-groups $(\mathbf{2 8 b}, \mathbf{4 1 d})$. The latter enables to incorporate the nonyl-substituted calix[4] arene 1,3-diketones into polydiacetylene (PDA) vesicles resulting in the formation of the mixed water dispersible aggregates, where the nonyl groups are included into the hydrophobic layer of PDA vesicles, while hydrophilic 1,3-diketone moieties are exposed at the hydrophilic surface. The nano-architecture of the mixed vesicles is schematically illustrated in Figure 17. The proximity of 1,3-diketone to carboxy/carboxylate groups facilitates the diketone-to-1,3diketonate transformation resulting in coordination of $\mathrm{Tb}^{3+}$ ions which, in turn, is followed by the enhancement of the $\mathrm{Tb}^{3+}$-centered luminescence [117].

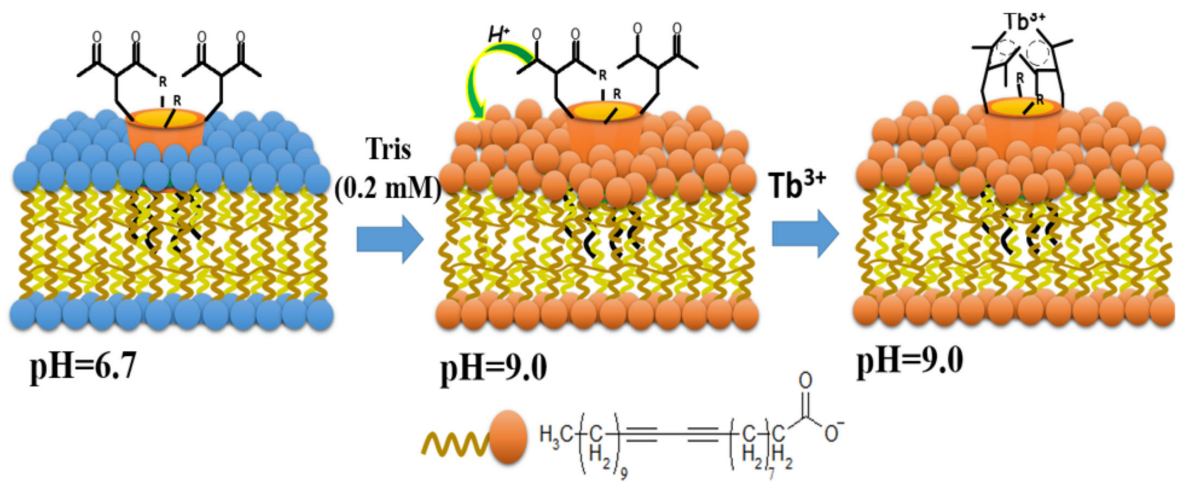

Figure 17. Schematic illustration of proton-pump effect of the carboxylate-groups of polydiacetylene (PDA)-vesicles on the coordination of $\mathrm{Tb}^{3+}$ ions via 1,3-diketonate groups of $\mathbf{2 8 b}$ and $\mathbf{4 1 d}$ embedded into the PDA vesicles. Reproduced from Ref. [117] with permission from the Elsevier.

\section{Conclusions}

The above presented results highlight synthetic routes for achieving the structural diversity of cyclophanic 1,3-diketones as versatile ligands for the formation of lanthanide complexes exhibiting both lanthanide-centered luminescence and magnetic relaxivity parameters convenient for contrast effect in MRI. The relationship between structural features of the cyclophanic 1,3-diketones and their complex ability is considered as a tool 
to control both functional properties of the produced complexes and their conversion into nanoparticulate forms. It is worth noting the advantages of the 1,3-diketone calix[4]arenebased ligands in developing of sensors and contrast agents.

(1) The embedding of two or four 1,3-diketone moieties onto the cyclophanic backbone favors the bis-chelating coordination mode of lanthanide ions. The tight binding of the bis-chelated lanthanide ions along with the low water solubility of the cyclophanic ligands facilitates safe conversion of the lanthanide complexes into the water dispersible nanoparticulate form.

(2) The bis-chelating coordination mode of the lanthanide ions both remains enough hydration numbers in the lanthanide complexes with 1,3-diketone calix[4]arenes and restricts leaching of $\mathrm{Ln}^{3+}$ ions from the nanoprecipitates. This is the prerequisite for their sensing ability in aqueous media and efficient contrast effect in MRI.

(3) The presence of the calix[4]arene backbone opens the opportunity of embedding different substituents onto lower or upper cyclophanic rims as a tool for tuning the terbium- or ytterbium-centered luminescence. Moreover, it is also shown that the embedding of the hydrophobic substituents enables to diversify the nanoparticulate forms of the $\mathrm{Tb}^{3+}$ complexes.

(4) The wide range of topologies of the cyclophanic backbones-calix[4]arene, calix[4]resorcinarene or thiacalix[4]arene-provides another tool for tuning both magnetic relaxation and luminescent properties through the structural diversity of the coordination modes of lanthanide ions. In turn, the substitution of the thiacalix[4]arene ligand enables to control its antenna effect on the terbium-centered luminescence through the modification of the triplet energy level.

Finally, from the results presented above it is clear that the cyclophanic 1,3-diketones can be considered as versatile building blocks for the construction of new nanosensors, fluorescent cellular contrast agents and gadolinium-containing contrast agents for MRI with improved functional parameters. We hope that this review will both open a new chapter of molecular design of 1,3-diketone calix[4]arenes and facilitate their use in various applications.

Funding: The work was funded by the Government assignment for FRC Kazan Scientific Center of RAS.

Institutional Review Board Statement: Not applicable.

Informed Consent Statement: Not applicable.

Data Availability Statement: Not applicable.

Conflicts of Interest: The authors declare no conflict of interest.

\section{References}

1. Steed, J.W.; Turner, D.R.; Wallace, K.J. Core Concepts in Supramolecular Chemistry and Nanochemistry; John Wiley: West Sussex, UK, 2007; ISBN 9780470858660.

2. $\quad$ Gleiter, R.; Hopf, H. (Eds.) Modern Cyclophane Chemistry; Wiley-VCH: Weinheim, Germany, 2004; ISBN 9783527307135.

3. Böhmer, V. Calixarenes, macrocycles with (almost) unlimited possibilities. Angew. Chemie Int. Ed. Engl. 1995, 34, 713-745. [CrossRef]

4. Gutsche, C.D. Calixarenes: An introduction, 2nd ed.; Monographs in Supramolecular Chemistry; Royal Society of Chemistry: Cambridge, UK, 2008; ISBN 978-0-85404-258-6.

5. Vicens, J.; Harrowfield, J.; Baklouti, L. (Eds.) Calixarenes in the Nanoworld; Springer: Berlin/Heidelberg, Germany, 2007; ISBN 1402050216.

6. Neri, P.; Sessler, J.L.; Wang, M.X. Calixarenes and Beyond; Springer: Berlin/Heidelberg, Germany, $2016 ;$ ISBN 9783319318677.

7. Kumar, R.; Sharma, A.; Singh, H.; Suating, P.; Kim, H.S.; Sunwoo, K.; Shim, I.; Gibb, B.C.; Kim, J.S. Revisiting fluorescent calixarenes: From molecular sensors to smart materials. Chem. Rev. 2019, 119, 9657-9721. [CrossRef] [PubMed]

8. Skorjanc, T.; Benyettou, F.; Olsen, J.C.; Trabolsi, A. Design of organic macrocycle-modified iron oxide nanoparticles for drug delivery. Chem. A Eur. J. 2017, 23, 8333-8347. [CrossRef] [PubMed] 
9. Eddaif, L.; Shaban, A.; Telegdi, J. Sensitive detection of heavy metals ions based on the calixarene derivatives-modified piezoelectric resonators: A review. Int. J. Environ. Anal. Chem. 2019, 99, 824-853. [CrossRef]

10. Haino, T. Designer supramolecular polymers with specific molecular recognitions. Polym. J. 2019, 51, 303-318. [CrossRef]

11. Kongor, A.R.; Mehta, V.A.; Modi, K.M.; Panchal, M.K.; Dey, S.A.; Panchal, U.S.; Jain, V.K. Calix-based nanoparticles: A review. Top. Curr. Chem. 2016, 374, 1-46. [CrossRef] [PubMed]

12. Asfari, M.-Z.; Böhmer, J.; Harrowfield, J.; Vicens, J. (Eds.) Calixarenes 2001; Kluwer Academic Publishers: Dordrecht, The Netherlands, 2002.

13. Lavendomme, R.; Zahim, S.; De Leener, G.; Inthasot, A.; Mattiuzzi, A.; Luhmer, M.; Reinaud, O.; Jabin, I. Rational strategies for the selective functionalization of calixarenes. Asian J. Org. Chem. 2015, 4, 710-722. [CrossRef]

14. Solovieva, S.E.; Burilov, V.A.; Antipin, I.S. Thiacalix[4]arene's lower rim derivatives: Synthesis and supramolecular properties. Macroheterocycles 2017, 10, 134-146. [CrossRef]

15. Gajjar, J.A.; Vekariya, R.H.; Parekh, H.M. Recent advances in upper rim functionalization of resorcin[4]arene derivatives: Synthesis and applications. Synth. Commun. 2020, 50, 2545-2571. [CrossRef]

16. Gloe, K. (Ed.) Macrocyclic Chemistry: Current Trends and Future Perspectives; Springer: Dordrecht, The Netherlands, 2005; ISBN 9781402033643.

17. Tasker, P.A.; Gasperov, V. Ligand design for base metal recovery. In Macrocyclic Chemistry_Current Trends and Future Perspectives; Gloe, K., Ed.; Springer: Berlin/Heidelberg, Germany, 2005; pp. 365-382.

18. Konczyk, J.; Nowik-Zajac, A.; Kozlowski, C.A. Calixarene-based extractants for heavy metal ions removal from aqueous solutions. Sep. Sci. Technol. 2016, 51, 2394-2410. [CrossRef]

19. Staniszewski, B.; Urbaniak, W. A simple and efficient synthesis of 3-substituted derivatives of pentane-2,4-dione. Chem. Pap. 2009, 63. [CrossRef]

20. Kel'in, A.; Maioli, A. Recent advances in the chemistry of 1,3-diketones: Structural modifications and synthetic applications. Curr. Org. Chem. 2005, 7, 1855-1886. [CrossRef]

21. Pradhan, J.; Goyal, A. $\beta$-diketones: Important intermediates for drug synthesis. Int. J. Pharm. Res. Allied Sci. 2015, 4, 1-18.

22. Kljun, J.; Turel, I. $\beta$-Diketones as scaffolds for anticancer drug design-From organic building blocks to natural products and metallodrug components. Eur. J. Inorg. Chem. 2017, 2017, 1655-1666. [CrossRef]

23. Binnemans, K. Rare-earth beta-diketonates. Handb. Phys. Chem. Rare Earths 2005, 35, 107-272. [CrossRef]

24. Vigato, P.A.; Peruzzo, V.; Tamburini, S. The evolution of $\beta$-diketone or $\beta$-diketophenol ligands and related complexes. Coord. Chem. Rev. 2009, 253, 1099-1201. [CrossRef]

25. Brock, A.J.; Clegg, J.K.; Li, F.; Lindoy, L.F. Recent developments in the metallo-supramolecular chemistry of oligo- $\beta$-diketonato ligands. Coord. Chem. Rev. 2018, 375, 106-133. [CrossRef]

26. Chen, B.; Fronczek, F.R.; Maverick, A.W. Porous $\mathrm{Cu}-\mathrm{Cd}$ mixed-metal-organic frameworks constructed from $\mathrm{Cu}(\mathrm{Pyac}) 2$ (bis[3-(4-pyridyl)pentane-2,4-dionato]copper(II)). Inorg. Chem. 2004, 43, 8209-8211. [CrossRef]

27. Clegg, J.K.; Iremonger, S.S.; Hayter, M.J.; Southon, P.D.; Macquart, R.B.; Duriska, M.B.; Jensen, P.; Turner, P.; Jolliffe, K.A.; Kepert, C.J.; et al. Hierarchical self-assembly of a chiral metal-organic framework displaying pronounced porosity. Angew. Chem. Int. Ed. 2010, 49, 1075-1078. [CrossRef]

28. Binnemans, K. Lanthanide-based luminescent hybrid materials. Chem. Rev. 2009, 109, 4283-4374. [CrossRef]

29. De Sá, G.; Malta, O.; de Mello Donegá, C.; Simas, A.; Longo, R.; Santa-Cruz, P.; da Silva, E. Spectroscopic properties and design of highly luminescent lanthanide coordination complexes. Coord. Chem. Rev. 2000, 196, 165-195. [CrossRef]

30. Brunet, E.; Juanes, O.; Rodriguez-Ubis, J. Supramolecularly Organized Lanthanide Complexes for Efficient Metal Excitation and Luminescence as Sensors in Organic and Biological Applications. Curr. Chem. Biol. 2012, 1, 11-39. [CrossRef]

31. Bünzli, J.C.G.; Piguet, C. Taking advantage of luminescent lanthanide ions. Chem. Soc. Rev. 2005, 34, 1048-1077. [CrossRef] [PubMed]

32. Mara, D.; Artizzu, F.; Laforce, B.; Vincze, L.; Van Hecke, K.; Van Deun, R.; Kaczmarek, A.M. Novel tetrakis lanthanide $\beta$-diketonate complexes: Structural study, luminescence properties and temperature sensing. J. Lumin. 2019, 213, 343-355. [CrossRef]

33. Cho, U.; Chen, J.K. Lanthanide-based optical probes of biological systems. Cell Chem. Biol. 2020, 27, 921-936. [CrossRef]

34. Gupta, S.K.; Kadam, R.M.; Pujari, P.K. Lanthanide spectroscopy in probing structure-property correlation in multi-site photoluminescent phosphors. Coord. Chem. Rev. 2020, 420, 213405. [CrossRef]

35. Hemmilä, I.; Laitala, V. Progress in lanthanides as luminescent probes. J. Fluoresc. 2005, 15, 529-542. [CrossRef] [PubMed]

36. Hemmila, I. Time-resolved fluorometric determination of terbium in aqueous solution. Anal. Chem. 1985, 57, 1676-1681. [CrossRef]

37. Heffern, M.C.; Matosziuk, L.M.; Meade, T.J. Lanthanide probes for bioresponsive imaging. Chem. Rev. 2014, 114, 4496-4539. [CrossRef]

38. Kaczmarek, M. Lanthanide-sensitized luminescence and chemiluminescence in the systems containing most often used medicines; a review. J. Lumin. 2020, 222, 117174. [CrossRef]

39. Meshkova, S.B.; Doga, P.G. Increasing Sensitivity of the Luminescence Determination of Lanthanides Using Their Complexes. J. Anal. Chem. 2020, 75, 286-303. [CrossRef]

40. Yang, Y.; Liu, X.; Nakamura, A.; Binnemans, K.; Liu, J. Pressure-induced phase transitions on a liquid crystalline europium(III) Complex. J. Phys. Chem. B 2008, 112, 5291-5295. [CrossRef] 
41. Yang, Y.; Li, J.; Liu, X.; Zhang, S.; Driesen, K.; Nockemann, P.; Binnemans, K. Listening to Lanthanide Complexes: Determination of the Intrinsic Luminescence Quantum Yield by Nonradiative Relaxation. ChemPhysChem 2008, 9, 600-606. [CrossRef] [PubMed]

42. Fujimoto, K.; Shinkai, S. Synthesis of and amine recognition with a Cu(II)-bridged biscalix[4]arene. Tetrahedron Lett. 1994, 35, 2915-2918. [CrossRef]

43. Senthilvelan, A.; Tsai, M.T.; Chang, K.C.; Chung, W.S. Mo(CO)6-mediated synthesis of calix[4]arenes carrying $\beta$-hydroxy ketones or $\alpha, \beta$-unsaturated- $\beta$-amino ketones. Tetrahedron Lett. 2006, 47, 9077-9081. [CrossRef]

44. Kuno, L.; Biali, S.E. Calix[4]arenes with two different chemical modifications at the bridges. J. Org. Chem. 2011, 76, 3664-3675. [CrossRef]

45. Kogan, K.; Biali, S.E. Incorporation of substituents at the methylene linkages of the calix[5]arene skeleton. J. Org. Chem. 2009, 74, 7172-7175. [CrossRef] [PubMed]

46. Kogan, K.; Columbus, I.; Biali, S.E. Functionalization of the methylene bridges of the calix[6]arene scaffold. J. Org. Chem. 2008, 73, 7327-7335. [CrossRef] [PubMed]

47. Itzhak, N.; Kogan, K.; Biali, S.E. Preparation of calix[8]arene derivatives functionalized at a single methylene bridge. Eur. J. Org. Chem. 2011, 6581-6585. [CrossRef]

48. Jiang, X.F.; Cui, Y.X.; Yu, S.Y. Design and synthesis of a new kind of cavitand: Tetrapyrazolylcalix[4] arenes and their supramolecular assemblies. Synlett 2014, 25, 1181-1185. [CrossRef]

49. Luo, Z.G.; Zhao, Y.; Ma, C.; Cao, L.; Ai, S.H.; Hu, J.S.; Xu, X.M. Synthesis, crystal structure and anti-integrase activity of 25,27-bis[(Z)-4-(p-methoxyphenyl)-4-hydroxybut-3-en-2-one-1-methyl]-26,28-dihydroxycalix[4]arene. Chin. J. Struct. Chem. 2014, $33,1117-1122$.

50. Luo, Z.G.; Zhao, Y.; Ma, C.; Xu, X.M.; Zhang, X.M.; Huang, N.Y.; He, H.Q. Synthesis and anti-integrase evaluation of novel calix[4]arene derivatives containing the triazolyl 1,3-diketo moiety. Chin. Chem. Lett. 2014, 25, 737-740. [CrossRef]

51. Luo, Z.; Zhao, Y.; Ma, C.; Li, Z.; Xu, X.; Hu, L.; Huang, N.; He, H. Synthesis, biological evaluation and molecular docking of calix[4]arene-based $\beta$-diketo derivatives as HIV-1 integrase inhibitors. Arch. Pharm. 2015, 348, 206-213. [CrossRef]

52. Podyachev, S.N.; Sudakova, S.N.; Galiev, A.K.; Mustafina, A.R.; Syakaev, V.V.; Shagidullin, R.R.; Bauer, I.; Konovalov, A.I. Synthesis of tris( $\beta$-diketones) and study of their complexation with some transition metals. Russ. Chem. Bull. 2006, 55, $2000-2007$. [CrossRef]

53. Shamsutdinova, N.A.; Podyachev, S.N.; Sudakova, S.N.; Mustafina, A.R.; Zairov, R.R.; Burilov, V.A.; Nizameev, I.R.; Rizvanov, I.K.; Syakaev, V.V.; Gabidullin, B.M.; et al. A facile synthetic route to convert $\mathrm{Tb}(\mathrm{III})$ complexes of novel tetra-1,3-diketone calix[4]resorcinarene into hydrophilic luminescent colloids. New J. Chem. 2014, 38, 4130-4140. [CrossRef]

54. Zairov, R.; Shamsutdinova, N.; Podyachev, S.; Sudakova, S.; Gimazetdinova, G.; Rizvanov, I.; Syakaev, V.; Babaev, V.; Amirov, R.; Mustafina, A. Structure impact in antenna effect of novel upper rim substituted tetra-1,3-diketone calix[4]arenes on $\mathrm{Tb}(\mathrm{III}) \mathrm{green}$ and $\mathrm{Yb}$ (III) NIR-luminescence. Tetrahedron 2016, 72, 2447-2455. [CrossRef]

55. Podyachev, S.N.; Sudakova, S.N.; Gimazetdinova, G.S.; Shamsutdinova, N.A.; Syakaev, V.V.; Barsukova, T.A.; Iki, N.; Lapaev, D.V.; Mustafina, A.R. Synthesis, metal binding and spectral properties of novel bis-1,3-diketone calix[4]arenes. New J. Chem. 2017, 41, 1526-1537. [CrossRef]

56. Gutsche, C.D.; Nam, K.C. Calixarenes. 22. Synthesis, properties, and metal complexation of aminocalixarenes. J. Am. Chem. Soc. 1988, 110, 6153-6162. [CrossRef] [PubMed]

57. Almi, M.; Arduini, A.; Casnati, A.; Pochini, A.; Ungaro, R. Chloromethylation of calixarenes and synthesis of new water soluble macrocyclic hosts. Tetrahedron 1989, 45, 2177-2182. [CrossRef]

58. Podyachev, S.N.; Sudakova, S.N.; Gimazetdinova, G.S.; Nagimov, R.N.; Gubaidullin, A.T.; Syakaev, V.V.; Lapaev, D.V.; Bazanova, O.B. The enhancement of luminescent properties of $\mathrm{Tb}^{3+}$ complexes with tetra-1,3-diketone ligands promoted by the tetrathiacalix[4]arene scaffold. Tetrahedron Lett. 2018, 59, 2695-2699. [CrossRef]

59. Podyachev, S.N.; Gimazetdinova, G.S.; Sudakova, S.N.; Shamsutdinova, N.A.; Lapaev, D.V.; Syakaev, V.V.; Gubaidullin, A.T.; Nagimov, R.N.; Mustafina, A.R. Influence of upper rim dibromo-substitution in bis-1,3-diketone calix[4]arenes on spectral properties of ligands and their lanthanide complexes. Tetrahedron 2017, 73, 5397-5407. [CrossRef]

60. Podyachev, S.N.; Sudakova, S.N.; Nagimov, R.N.; Masliy, A.N.; Syakaev, V.V.; Lapaev, D.V.; Buzyurova, D.N.; Babaev, V.M.; Gimazetdinova, G.S.; Kuznetsov, A.M.; et al. A simple synthetic approach to enhance the thermal luminescence sensitivity of $\mathrm{Tb}^{3+}$ complexes with thiacalix[4]arene derivatives through upper-rim bromination. Dalton Trans. 2020, 49, 8298-8313. [CrossRef] [PubMed]

61. Zairov, R.R.; Nagimov, R.N.; Sudakova, S.N.; Lapaev, D.V.; Syakaev, V.V.; Gimazetdinova, G.S.; Voloshina, A.D.; Shykula, M.; Nizameev, I.R.; Samigullina, A.I.; et al. Polystyrenesulfonate-coated nanoparticles with low cytotoxicity for determination of copper(II) via the luminescence of $\mathrm{Tb}(\mathrm{III})$ complexes with new calix[4]arene derivatives. Microchim. Acta 2018, 185, 386. [CrossRef] [PubMed]

62. Emsley, J. The composition, structure and hydrogen bonding of the $\beta$-diketones. In Complex Chemistry; Springer: Berlin/Heidelberg, Germany, 1984; pp. 147-191.

63. Gomes, J.R.B.; Ribeiro da Silva, M.A.V. Computational study on the bond dissociation enthalpies in the enolic and ketonic forms of $\beta$-diketones: Their influence on metal-ligand bond enthalpies. J. Phys. Chem. A 2006, 110, 13948-13955. [CrossRef]

64. Yamabe, S.; Tsuchida, N.; Miyajima, K. Reaction paths of keto-enol tautomerization of $\beta$-diketones. J. Phys. Chem. A 2004, 108, 2750-2757. [CrossRef] 
65. García-Río, L.; Mejuto, J.C.; Parajó, M.; Pérez-Lorenzo, M. First kinetic discrimination between carbon and oxygen reactivity of enols. J. Org. Chem. 2008, 73, 8198-8205. [CrossRef]

66. Srinivasan, R.; Feenstra, J.S.; Park, S.T.; Xu, S.; Zewail, A.H. Direct determination of hydrogen-bonded structures in resonant and tautomeric reactions using ultrafast electron diffraction. J. Am. Chem. Soc. 2004, 126, 2266-2267. [CrossRef]

67. Hansen, P.E.; Spanget-Larsen, J. NMR and IR investigations of strong intramolecular hydrogen bonds. Molecules 2017, $22,552$. [CrossRef]

68. Le, Q.T.H.; Umetani, S.; Suzuki, M.; Matsui, M. $\alpha$-Substituted $\beta$-diketones: Effect of the $\alpha$ substituent on the complexation and selectivity for lanthanides. J. Chem. Soc. Dalton Trans. 1997, 643-648. [CrossRef]

69. Podyachev, S.N.; Sudakova, S.N.; Nagimov, R.N.; Lapaev, D.V.; Masliy, A.N.; Syakaev, V.V.; Bazanova, O.B.; Gimazetdinova, G.S.; Babaev, V.M.; Kuznetsov, A.M.; et al. Structural and photophysical properties of $\mathrm{Tb}^{3+}$-tetra-1,3-diketonate complexes controlled by calix[4]arene-tetrathiacalix[4]arene scaffolds. Dalton Trans. 2019, 48, 3930-3940. [CrossRef]

70. Podyachev, S.N.; Gimazetdinova, G.S.; Sudakova, S.N.; Lapaev, D.V.; Syakaev, V.V.; Nagimov, R.N. Synthesis of 1,3-diketo derivatives of calix[4]arene with nonyl substituents at the lower rim as novel efficient sensibilizers of $\mathrm{Tb}^{3+}$ luminescence. Russ. J. Gen. Chem. 2017, 87, 1958-1968. [CrossRef]

71. Massi, M.; Odgen, M.I. Luminescent lanthanoid calixarene complexes and materials. Materials 2017, 10, 1369. [CrossRef] [PubMed]

72. Iki, N.; Miyano, S. Can thiacalixarene surpass calixarene? J. Incl. Phenom. 2001, 41, 99-105. [CrossRef]

73. Iki, N.; Horiuchi, T.; Oka, H.; Koyama, K.; Morohashi, N.; Kabuto, C.; Miyano, S. Energy transfer luminescence of Tb ${ }^{3+}$ ion complexed with calix[4]arenetetrasulfonate and the thia and sulfonyl analogue. The effect of bridging groups. J. Chem. Soc. Perkin Trans. 2 2001, 2219-2225. [CrossRef]

74. Bünzli, J.C.G. On the design of highly luminescent lanthanide complexes. Coord. Chem. Rev. 2015, 293-294, 19-47. [CrossRef]

75. Hyre, A.S.; Doerrer, L.H. A structural and spectroscopic overview of molecular lanthanide complexes with fluorinated O-donor ligands. Coord. Chem. Rev. 2020, 404, 213098. [CrossRef]

76. Lapaev, D.V.; Nikiforov, V.G.; Lobkov, V.S.; Knyazev, A.A.; Galyametdinov, Y.G. A photostable vitrified film based on a terbium(III) $\beta$-diketonate complex as a sensing element for reusable luminescent thermometers. J. Mater. Chem. C 2018, 6, 9475-9481. [CrossRef]

77. Brites, C.D.S.; Lima, P.P.; Silva, N.J.O.; Millán, A.; Amaral, V.S.; Palacio, F.; Carlos, L.D. Lanthanide-based luminescent molecular thermometers. New J. Chem. 2011, 35, 1177-1183. [CrossRef]

78. Hasegawa, Y.; Kitagawa, Y. Thermo-sensitive luminescence of lanthanide complexes, clusters, coordination polymers and metal-organic frameworks with organic photosensitizers. J. Mater. Chem. C 2019, 7, 7494-7511. [CrossRef]

79. Brites, C.D.S.; Balabhadra, S.; Carlos, L.D. Lanthanide-based thermometers: At the cutting-edge of luminescence thermometry. Adv. Opt. Mater. 2019, 7, 1-30. [CrossRef]

80. Davydov, N.; Mustafina, A.; Burilov, V.; Zvereva, E.; Katsyuba, S.; Vagapova, L.; Konovalov, A.; Antipin, I. Complex formation of $d$-metal ions at the interface of $\mathrm{Tb}^{\mathrm{III}}$-doped silica nanoparticles as a Basis of substrate-responsive $\mathrm{Tb}^{\mathrm{III}}$-centered luminescence. ChemPhysChem 2012, 13, 3357-3364. [CrossRef]

81. Zairov, R.; Mustafina, A.; Shamsutdinova, N.; Rümmeli, M.H.; Amirov, R.; Burilov, V.; Pinus, M.; Morozov, V.; Ivanov, V.; Gogolashvili, E.; et al. The effect of the core morphology of Eu(III)-doped nanoparticles on the ion exchange versus energy transfer between $\mathrm{Eu}(\mathrm{III})$ in the core and $\mathrm{Cu}(\mathrm{II})$ ions at the interface. J. Nanopart. Res. 2012, 14, 1018. [CrossRef]

82. Lapaev, D.V.; Nikiforov, V.G.; Lobkov, V.S.; Knyazev, A.A.; Ziyatdinova, R.M.; Galyametdinov, Y.G. A vitrified film of an anisometric europium(iii) $\beta$-diketonate complex with a low melting point as a reusable luminescent temperature probe with excellent sensitivity in the range of 270-370 K. J. Mater. Chem. C 2020, 8, 6273-6280. [CrossRef]

83. Aikawa, T.; Mizuno, A.; Kohri, M.; Taniguchi, T.; Kishikawa, K.; Nakahira, T. Polystyrene latex particles containing europium complexes prepared by miniemulsion polymerization using bovine serum albumin as a surfactant for biochemical diagnosis. Colloids Surf. B Biointerfaces 2016, 145, 152-159. [CrossRef]

84. Huhtinen, P.; Kivelä, M.; Kuronen, O.; Hagren, V.; Takalo, H.; Tenhu, H.; Lövgren, T.; Härmä, H. Synthesis, characterization, and application of $\mathrm{Eu}(\mathrm{III}), \mathrm{Tb}(\mathrm{III}), \mathrm{Sm}(\mathrm{III})$, and Dy(III) lanthanide chelate nanoparticle labels. Anal. Chem. 2005, 77, 2643-2648. [CrossRef] [PubMed]

85. Chandra, A.; Prasad, S.; Gigli, G.; del Mercato, L.L. Fluorescent Nanoparticles for Sensing, 1st ed.; Elsevier Ltd.: Amsterdam, The Netherlands, 2020; Volume 16, ISBN 9780081028285.

86. Shamsipur, M.; Barati, A.; Nematifar, Z. Fluorescent pH nanosensors: Design strategies and applications. J. Photochem. Photobiol. C Photochem. Rev. 2019, 39, 76-141. [CrossRef]

87. Mustafina, A.R.; Fedorenko, S.V.; Konovalova, O.D.; Menshikova, A.Y.; Shevchenko, N.N.; Soloveva, S.E.; Konovalov, A.I.; Antipin, I.S. Novel highly charged silica-coated $\mathrm{Tb}(\mathrm{III})$ nanoparticles with fluorescent properties sensitive to ion exchange and energy transfer processes in aqueous dispersions. Langmuir 2009, 25, 3146-3151. [CrossRef]

88. Das, A.; Mohanty, S.; Kumar, R.; Kuanr, B.K. Tailoring the Design of a Lanthanide Complex/Magnetic Ferrite Nanocomposite for Efficient Photoluminescence and Magnetic Hyperthermia Performance. ACS Appl. Mater. Interfaces 2020, 12, 42016-42029. [CrossRef]

89. Chen, Y.; Chi, Y.; Wen, H.; Lu, Z. Sensitized luminescent terbium nanoparticles: Preparation and time-resolved fluorescence assay for DNA. Anal. Chem. 2007, 79, 960-965. [CrossRef] 
90. Ai, K.; Zhang, B.; Lu, L. Europium-based fluorescence nanoparticle sensor for rapid and ultrasensitive detection of an anthrax biomarker. Angew. Chem. Int. Ed. 2009, 48, 304-308. [CrossRef] [PubMed]

91. Wang, Q.X.; Xue, S.F.; Chen, Z.H.; Ma, S.H.; Zhang, S.; Shi, G.; Zhang, M. Dual lanthanide-doped complexes: The development of a time-resolved ratiometric fluorescent probe for anthrax biomarker and a paper-based visual sensor. Biosens. Bioelectron. 2017, 94, 388-393. [CrossRef]

92. Wu, Y.; Shi, M.; Zhao, L.; Feng, W.; Li, F.; Huang, C. Visible-light-excited and europium-emissive nanoparticles for highlyluminescent bioimaging invivo. Biomaterials 2014, 35, 5830-5839. [CrossRef]

93. Santos, J.A.O.; Mutti, A.M.G.; Bispo-Jr, A.G.; Pires, A.M.; Lima, S.A.M. Red-emitting hybrid based on Eu ${ }^{3+}$-dbm complex anchored on silica nanoparticles surface by carboxylic acid for biomarker application. Materials 2020, 13, 5494. [CrossRef] [PubMed]

94. Ma, H.; Song, B.; Wang, Y.; Cong, D.; Jiang, Y.; Yuan, J. Dual-emissive nanoarchitecture of lanthanide-complex-modified silica particles for in vivo ratiometric time-gated luminescence imaging of hypochlorous acid. Chem. Sci. 2016, 8, 150-159. [CrossRef]

95. Li, X.; Lu, S.; Tu, D.; Zheng, W.; Chen, X. Luminescent lanthanide metal-organic framework nanoprobes: From fundamentals to bioapplications. Nanoscale 2020, 12, 15021-15035. [CrossRef]

96. Zheng, C.; Ren, H.; Cui, Z.; Chen, F.; Hong, G. Synthesis and characterization of nano-scale Terbium (III)-trimesic acid (TMA)1,10-phenanthroline(phen) luminescent complex. J. Alloys Compd. 2009, 477, 333-336. [CrossRef]

97. Nishiyabu, R.; Hashimoto, N.; Cho, T.; Watanabe, K.; Yasunaga, T.; Endo, A.; Kaneko, K.; Niidome, T.; Murata, M.; Adachi, C.; et al. Nanoparticles of Adaptive Supramolecular Networks Self-Assembled from Nucleotides and Lanthanide Ions. J. Am. Chem. Soc. 2009, 131, 2151-2158. [CrossRef]

98. Guo, J.; Tang, J.; Wang, J.; Mao, S.; Li, H.; Wang, Y.; Liu, J.; Wang, Y.; Huang, L.; Kipper, M.J.; et al. Europium(III)-induced water-soluble nano-aggregates of hyaluronic acid and chitosan: Structure and fluorescence. MRS Commun. 2018, 8, 1224-1229. [CrossRef]

99. Zairov, R.; Zhilkin, M.; Mustafina, A.; Nizameev, I.; Tatarinov, D.; Konovalov, A. Impact of polyelectrolyte coating in fluorescent response of $\mathrm{Eu}(\mathrm{III})$-containing nanoparticles on small chelating anions including nucleotides. Surf. Coat. Technol. 2015, 271, 242-246. [CrossRef]

100. Davydov, N.; Zairov, R.; Mustafina, A.; Syakayev, V.; Tatarinov, D.; Mironov, V.; Eremin, S.; Konovalov, A.; Mustafin, M. Determination of fluoroquinolone antibiotics through the fluorescent response of Eu(III) based nanoparticles fabricated by layer-by-layer technique. Anal. Chim. Acta 2013, 784. [CrossRef] [PubMed]

101. Mustafina, A.; Zairov, R.; Gruner, M.; Ibragimova, A.; Tatarinov, D.; Nizameyev, I.; Nastapova, N.; Yanilkin, V.; Kadirov, M.; Mironov, V.; et al. Synthesis and photophysical properties of colloids fabricated by the layer-by-layer polyelectrolyte assembly onto Eu(III) complex as a core. Colloids Surf. B Biointerfaces 2011, 88, 490-496. [CrossRef] [PubMed]

102. Zairov, R.R.; Tatarinov, D.A.; Shamsutdinova, N.A.; Mustafina, A.R.; Rizvanov, I.K.; Syakaev, V.V.; Mironov, V.F.; Konovalov, A.I. Polymethoxyphenyl-substituted [2-(5-chloro-2-hydroxy-4-methylphenyl)-2-phenylvinyl]phosphine oxides: Synthesis and complexation with Eu(TTA)3. Russ. J. Org. Chem. 2014, 50, 547-551. [CrossRef]

103. Palo, E.; Salomäki, M.; Lastusaari, M. Surface modification of upconverting nanoparticles by layer-by-layer assembled polyelectrolytes and metal ions. J. Colloid Interface Sci. 2017, 508, 137-144. [CrossRef] [PubMed]

104. Zhang, R.J.; Cui, J.W.; Lu, D.M.; Hou, W.G. Study on high-efficiency fluorescent microcapsules doped with europium $\beta$-diketone complex by LbL self-assembly. Chem. Commun. 2007, 1547-1549. [CrossRef] [PubMed]

105. Cui, J.W.; Zhang, R.J.; Lin, Z.G.; Li, L.; Jin, W.R. The effect of temperature and solvent on the morphology of microcapsules doped with a europium $\beta$-diketonate complex. J. Chem. Soc. Dalton Trans. 2007, 3, 895-899. [CrossRef]

106. Zairov, R.R.; Dovzhenko, A.P.; Sapunova, A.S.; Voloshina, A.D.; Tatarinov, D.A.; Nizameev, I.R.; Gubaidullin, A.T.; Petrov, K.A.; Enrichi, F.; Vomiero, A.; et al. Dual red-NIR luminescent Eu Yb heterolanthanide nanoparticles as promising basis for cellular imaging and sensing. Mater. Sci. Eng. C 2019, 105, 110057. [CrossRef]

107. Zairov, R.R.; Solovieva, A.O.; Shamsutdinova, N.A.; Podyachev, S.N.; Shestopalov, M.A.; Pozmogova, T.N.; Miroshnichenko, S.M.; Mustafina, A.R.; Karasik, A.A. Polyelectrolyte-coated ultra-small nanoparticles with Tb(III)-centered luminescence as cell labels with unusual charge effect on their cell internalization. Mater. Sci. Eng. C 2019, 95. [CrossRef] [PubMed]

108. Zairov, R.; Mustafina, A.; Shamsutdinova, N.; Nizameev, I.; Moreira, B.; Sudakova, S.; Podyachev, S.; Fattakhova, A.; Safina, G.; Lundstrom, I.; et al. High performance magneto-fluorescent nanoparticles assembled from terbium and gadolinium 1,3-diketones. Sci. Rep. 2017, 7. [CrossRef]

109. Shamsutdinova, N.; Zairov, R.; Mustafina, A.; Podyachev, S.; Sudakova, S.; Nizameev, I.; Kadirov, M.; Amirov, R. Interfacial interactions of hard polyelectrolyte-stabilized luminescent colloids with substrates. Colloids Surf. A Physicochem. Eng. Asp. 2015, 482, 231-240. [CrossRef]

110. Shamsutdinova, N.A.; Gubaidullin, A.T.; Odintsov, B.M.; Larsen, R.J.; Schepkin, V.D.; Nizameev, I.R.; Amirov, R.R.; Zairov, R.R.; Sudakova, S.N.; Podyachev, S.N.; et al. Polyelectrolyte-stabilized nanotemplates based on Gd(III) complexes with macrocyclic tetra-1,3-diketones as a positive MR contrast agents. ChemistrySelect 2016, 1, 1377-1383. [CrossRef]

111. Zairov, R.; Pizzanelli, S.; Dovzhenko, A.P.; Nizameev, I.; Orekhov, A.; Arkharova, N.; Podyachev, S.N.; Sudakova, S.; Mustafina, A.R.; Calucci, L. Paramagnetic Relaxation Enhancement in Hydrophilic Colloids Based on Gd(III) Complexes with Tetrathia- and Calix[4]arenes. J. Phys. Chem. C 2020, 124, 4320-4329. [CrossRef] 
112. Zairov, R.R.; Dovzhenko, A.P.; Sapunova, A.S.; Voloshina, A.D.; Sarkanich, K.A.; Daminova, A.G.; Nizameev, I.R.; Lapaev, D.V.; Sudakova, S.N.; Podyachev, S.N.; et al. Terbium(III)-thiacalix[4]arene nanosensor for highly sensitive intracellular monitoring of temperature changes within the 303-313 K range. Sci. Rep. 2020, 10, 1-13. [CrossRef]

113. Shamsutdinova, N.; Zairov, R.; Nizameev, I.; Gubaidullin, A.; Mukhametshina, A.; Podyachev, S.; Ismayev, I.; Kadirov, M.; Voloshina, A.; Mukhametzyanov, T.; et al. Tuning magnetic relaxation properties of "hard cores" in core-shell colloids by modification of "soft shell". Colloids Surf. B Biointerfaces 2018, 162, 52-59. [CrossRef] [PubMed]

114. Zairov, R.; Khakimullina, G.; Podyachev, S.; Nizameev, I.; Safiullin, G.; Amirov, R.; Vomiero, A.; Mustafina, A. Hydration number: Crucial role in nuclear magnetic relaxivity of Gd(III) chelate-based nanoparticles. Sci. Rep. 2017, 7. [CrossRef] [PubMed]

115. Zairov, R.R.; Shamsutdinova, N.A.; Fattakhova, A.N.; Pyataev, A.V.; Abdullin, A.F.; Gerasimov, A.V.; Gubaidullin, A.T.; Mustafina, A.R. Nanoparticles based on gadolinium(III) and europium(III) complexes for biovisualization. Russ. Chem. Bull. 2016, 65, 1325-1331. [CrossRef]

116. Caravan, P.; Farrar, C.T.; Frullano, L.; Uppal, R. Influence of molecular parameters and increasing magnetic field strength on relaxivity of gadolinium- and manganese-based T1 contrast agents. Contrast Media Mol. Imaging 2009, 4, 89-100. [CrossRef] [PubMed]

117. Elistratova, J.; Akhmadeev, B.; Zairov, R.; Dovzhenko, A.; Podyachev, S.; Sudakova, S.; Syakaev, V.; Jelinek, R.; Kolusheva, S.; Mustafina, A. $\mathrm{Tb}(\mathrm{III})$ complexes with nonyl-substituted calix[4]arenes as building blocks of hydrophilic luminescent mixed polydiacetylene-based aggregates. J. Mol. Liq. 2018, 268, 463-470. [CrossRef] 